\title{
Pituitary stem cell regulation: who is pulling the strings?
}

\author{
Benoit Cox*, Heleen Roose*, Annelies Vennekens and Hugo Vankelecom \\ Department of Development and Regeneration, Cluster of Stem Cell and Developmental Biology, \\ Unit of Stem Cell Research, University of Leuven (KU Leuven), Leuven, Belgium \\ *(B Cox and $\mathrm{H}$ Roose contributed equally to this work)
}

Correspondence should be addressed to $\mathrm{H}$ Vankelecom Email

Hugo.Vankelecom@ kuleuven.be

\begin{abstract}
The pituitary gland plays a pivotal role in the endocrine system, steering fundamental processes of growth, metabolism, reproduction and coping with stress. The adult pituitary contains resident stem cells, which are highly quiescent in homeostatic conditions. However, the cells show marked signs of activation during processes of increased cell remodeling in the gland, including maturation at neonatal age, adaptation to physiological demands, regeneration upon injury and growth of local tumors. Although functions of pituitary stem cells are slowly but gradually uncovered, their regulation largely remains virgin territory. Since postnatal stem cells in general reiterate embryonic developmental pathways, attention is first being given to regulatory networks involved in pituitary embryogenesis. Here, we give an overview of the current knowledge on the NOTCH, WNT, epithelial-mesenchymal transition, $\mathrm{SHH}$ and Hippo pathways in the pituitary stem/progenitor cell compartment during various (activation) conditions from embryonic over neonatal to adult age. Most information comes from expression analyses of molecular components belonging to these networks, whereas functional extrapolation is still very limited. From this overview, it emerges that the 'big five' embryonic pathways are indeed reiterated in the stem cells of the 'lazy' homeostatic postnatal pituitary, further magnified en route to activation in more energetic, physiological and pathological remodeling conditions. Increasing the knowledge on the molecular players that pull the regulatory strings of the pituitary stem cells will not only provide further fundamental insight in postnatal pituitary homeostasis and activation, but also clues toward the development of regenerative ideas for improving treatment of pituitary deficiency and tumors.
\end{abstract}

Key Words
- pituitary
- stem cells
- regulation
- homeostasis
- regeneration
- tumor
- NOTCH
- WNT
- Hedgehog
- epithelial-mesenchymal
transition
- Hippo
- SOX2

Journal of Endocrinology (2017) 234, R135-R158

\section{Pituitary stem cells: purported players in pituitary housekeeping}

The pituitary gland acts as the governor of the endocrine system, integrating inputs from the central hypothalamus and from peripheral grounds to adjust the output of endocrine glands to hormonal needs of the body. The pituitary consists of two major parts, the adenohypophysis and the neurohypophysis. The adenohypophysis contains the hormone-producing cells, located in the anterior pituitary (AP) or the intermediate lobe (IL). The AP harbors the cells responsible for the production of growth hormone (GH), prolactin (PRL), adrenocorticotropic hormone (ACTH), thyroid-stimulating hormone (TSH) and luteinizing hormone (LH)/follicle-stimulating hormone (FSH). The IL encompasses the cells that produce melanocyte-stimulating hormone (MSH),

Published by Bioscientifica Ltd. 
a protein also derived from the ACTH precursor molecule proopiomelanocortin (POMC). In addition to the endocrine cells, the adenohypophysis contains nonhormonal cells including endothelial cells that form the sinusoidal capillary network, supportive mesenchymal cells and folliculostellate cells that have multiple functions (Allaerts \& Vankelecom 2005, Susa et al. 2012).

Embryogenesis of the pituitary starts with invagination of the oral roof ectoderm, which expresses the pairedlike homeodomain transcription factor 1 (PITX1) and PITX2 and bulges toward the neural ectoderm of the ventral diencephalon (for extensive reviews, see Rizzoti \& Lovell-Badge 2005, Zhu et al. 2007, Kelberman et al. 2009, Vankelecom \& Gremeaux 2010, Vankelecom 2012). This invagination, known as Rathke's pouch (RP), is mainly composed of progenitor cells marked by expression of sex determining region Y-box 2 (SOX2) and later of Prophet of PIT1 (PROP1). RP then detaches from the oral ectoderm, to further expand and generate the different hormonal cell lineages under the influence of opposing gradients from morphogens (like fibroblast growth factor (FGF) and bone morphogenetic protein (BMP)) that drive the spatio-temporal expression of specific transcriptional regulators of hormonal lineage specification. For instance, PROP1 is essential for the formation of the cell lineage marked by POU domain, class 1 , transcription factor 1 (POU1F1), also known as the PIT1 lineage, which consists of somatotropes (producing GH), lactotropes (PRL) and thyrotropes (TSH). Eventually, the AP and IL are formed, still separated by a lumen remaining within the inflating $\mathrm{RP}$ and forming the later cleft (Rizzoti \& Lovell-Badge 2005, Zhu et al. 2007, Kelberman et al. 2009, Vankelecom \& Gremeaux 2010, Vankelecom 2012). In humans, the cleft between the adeno- and neurohypophysis is still discernible but the IL is not clearly demarcated anymore, and $\mathrm{MSH}$-expressing melanotropes and RP remnants are found dispersed within the AP (McNicol 1986, Garcia-Lavandeira 2009, 2012).

After birth, the pituitary further expands in size and cell number by an active neonatal growth wave, completed around postnatal day (P) 21 in mice (CarbajoPérez \& Watanabe 1990, Taniguchi et al. 2002). Following that period and throughout adulthood, the gland is fairly static with very low turnover during homeostasis. However, cell remodeling is regularly (re-)activated according to the endocrine needs. Adaptation of the cellular composition is observed during puberty (increase in somatotropes) and during pregnancy and lactation (expansion of lactotropes). Mechanisms underlying this pituitary plasticity, as well as the homeostatic turnover, are still uncertain (Melmed 2003). The increased number of a precise group of endocrine cells may be generated by mitosis of existing hormonal cells, by transdifferentiation between different hormonal cell lineages or by differentiation from resident stem cells.

Although the existence of stem cells in the pituitary was regularly hypothesized in the last 50 years (Yoshimura et al. 1969, Melmed 2003), the cells flew under the radar for a long time. In 2005, a side population (SP) of cells, distinguished by efflux capacity for Hoechst 33342 dye, was identified in the mouse adult AP and found to encompass cells possessing self-renewal and multipotent differentiation capacity, both fundamental hallmarks of stem cells (Chen et al. 2005). Further refinement pinpointed a SP subfraction (referred to as the stem cellside population or SC-SP) highly enriched in cells with stem cell characteristics and expressing stemness markers, in particular SOX2 and SOX9 (Chen et al. 2009). These and other markers (including E-cadherin, glial cell line derived neurotrophic factor family receptor alpha 2 or GFRA2, nestin and PROP1) were found in the cells of the marginal zone bordering the cleft (Fauquier et al. 2008, Gleiberman et al. 2008, Chen et al. 2009, GarciaLavandeira et al. 2009, Yoshida et al. 2011, 2014), with a similar expression and organization picture in human pituitary (Garcia-Lavandeira et al. 2009, 2012). In addition, SOX2+ cells were also found within the gland's parenchyma, mostly occurring in clusters and also expressing SOX9 and E-cadherin (Fauquier et al. 2008, Gremeaux et al. 2012, Chen et al. 2013, Rizzoti et al. 2013, Nantie et al. 2014, Zhu et al. 2015). The marginal zone and parenchymal clusters are proposed to represent plural stem cell niches in the pituitary to enable swift adaptation during (subtle) cell remodeling processes (Vankelecom 2012, Vankelecom \& Chen 2014). The different niches appear physically interconnected in a 3D network (Gremeaux et al. 2012, Mollard et al. 2012, Vankelecom \& Chen 2014, Vankelecom 2016). However, whether the stem cells at the different locations exhibit different properties, regulation and function is not clear. Some reports point to molecular distinctions, including differential expression of PROP1 and extracellular matrix components (Yoshida et al. 2011, 2014, 2016a).

Once pituitary stem cells were identified, the search started for unraveling their functional responsibilities in the gland. In general, stem cells in adult tissues are involved in tissue turnover, repair after injury and/or pathogenesis (like tumorigenesis) when their regulation goes awry. A pituitary injury model was developed in which somatotropes are destroyed by diphtheria toxin (DT)

Published by Bioscientifica Ltd. 
injection of GH-Cre/iDTR mice expressing the DT receptor (DTR) under control of the GH promoter (Fu et al. 2012). A first remarkable observation in this study was the considerable restoration of the GH-expressing $\left(\mathrm{GH}^{+}\right)$cells after 4-5 months, for the first time showing that the adult pituitary is capable of cell regeneration. Moreover, the stem cells were found to respond to the pituitary injury by expanding and expressing $\mathrm{GH}$, thus strongly supporting their involvement in the regenerative reaction. A similar process was observed in another pituitary injury model, i.e. the PRL-Cre/iDTR mouse in which lactotropes were killed by DT (Fu \& Vankelecom 2012). The studies together point to a more general regenerative competence of the pituitary and its stem cells (Willems \& Vankelecom 2014). This capability, however, quickly disappears with aging, coinciding with a decrease in stem cell number and fitness (as probed in the stem cell-driven sphere-forming assay) (Willems et al. 2016). Moreover, regeneration was not observed anymore after prolonged injury impact (i.e. 10 days of DT injection instead of 3 days), which may be due to exhaustion of the repeatedly activated stem cells during the extended injury impact (Willems et al. 2016). Genome-wide expression analysis identified several embryonic pathways in the stem cell compartment in these models, which may underlie the success or failure of the pituitary's regeneration (Willems et al. 2016), as further discussed below.

Whether pituitary stem cells are also involved in the gland's early-postnatal maturation and in the adult homeostatic turnover has recently been investigated. During the neonatal growth wave, pituitary stem cells are more abundant and more proliferative as compared to the stem cells in the adult gland and show higher expression of several components of key embryonic pathways like sonic hedgehog (SHH) and wingless-type MMTV integration site (WNT) (Yoshida et al. 2011, Gremeaux et al. 2012). In accordance, lineage tracing studies showed a larger contribution of the pituitary SOX2+ and SOX9+ stem cells to endocrine cells at young age than at adult age when pituitary turnover is very low, indicating that the stem cells are (more) active in early-postnatal maturation but largely quiescent under adult homeostatic conditions (Andoniadou et al. 2013, Rizzoti et al. 2013). However, endocrine changes triggering pituitary plastic adaptations seem to involve reactivation of the dormant stem cells in the adult gland. For instance, adrenalectomy causes a transient surge in ACTH-producing corticotropes of which $20 \%$ is derived from SOX9+ stem cells (Rizzoti et al. 2013). In addition, gonadectomy or in vivo estradiol treatment elicits a $\left(\mathrm{SOX}^{+}\right)$stem cell reaction showing higher proliferative activity (Rizzoti et al. 2013).

Although the functional position of the pituitary stem cells is being unveiled step by step, not much is known about the molecular regulation of the cells' activity during the execution of their several roles. In the first part of this review, we summarize what has presently been described regarding major regulatory pathways in the pituitary stem cell compartment during the different conditions of embryonic and neonatal development, homeostasis, adaptation and regeneration. In the second part, we discuss what is known about these pathways in pituitary tumorigenesis. We describe the pathways in a 'downstream' logic, i.e. from ligands to receptors to intracellular signals.

\section{NOTCH pathway: contained Janus-type regulator of the pituitary stem cells?}

The NOTCH pathway is a well-known regulatory system essential for embryonic development of many organs, particularly regarding cell fate decisions during organogenesis. NOTCH signaling is activated by binding of the membrane-tethered ligands Jagged (JAG1, 2) and Delta-like (DLL1, 3, 4) to the NOTCH1-4 receptors on adjacent cells (Baladrón et al. 2005) (Fig. 1A). Binding induces cleavage of the intracellular domain of the NOTCH receptor (NICD) by $\gamma$-secretases. The released NICD subsequently migrates into the nucleus to combine with the core NOTCH transcription factor recombination signal-binding protein for immunoglobulin kappa J region (RBP-J) and co-transcriptional activators like Mastermind-like. The formed complex activates the expression of various downstream target genes such as the basic helix-loop-helix hairy and enhancer of split-1 (HES) and HES-related with YRPW motif 1 (HEY) transcription factor family (e.g. Hes1, Hey1) (Braune \& Lendahl 2016). NOTCH signaling induces divergent cell fates starting from an initially uniform cell pool through a process called 'lateral inhibition' (Sprinzak et al. 2010). Neighboring cells inhibit each other to coexpress within the same cell both NOTCH receptors and ligands. This mechanism eventually generates a mosaic pattern in which NOTCH-receptive cells alternate with ligandexpressing cells, thereby inducing different cell fates within a previously identical population (Sprinzak et al. 2010). Applied to stem cells, NOTCH activation in general keeps the cells undifferentiated through the HES/HEY
Published by Bioscientifica Ltd 

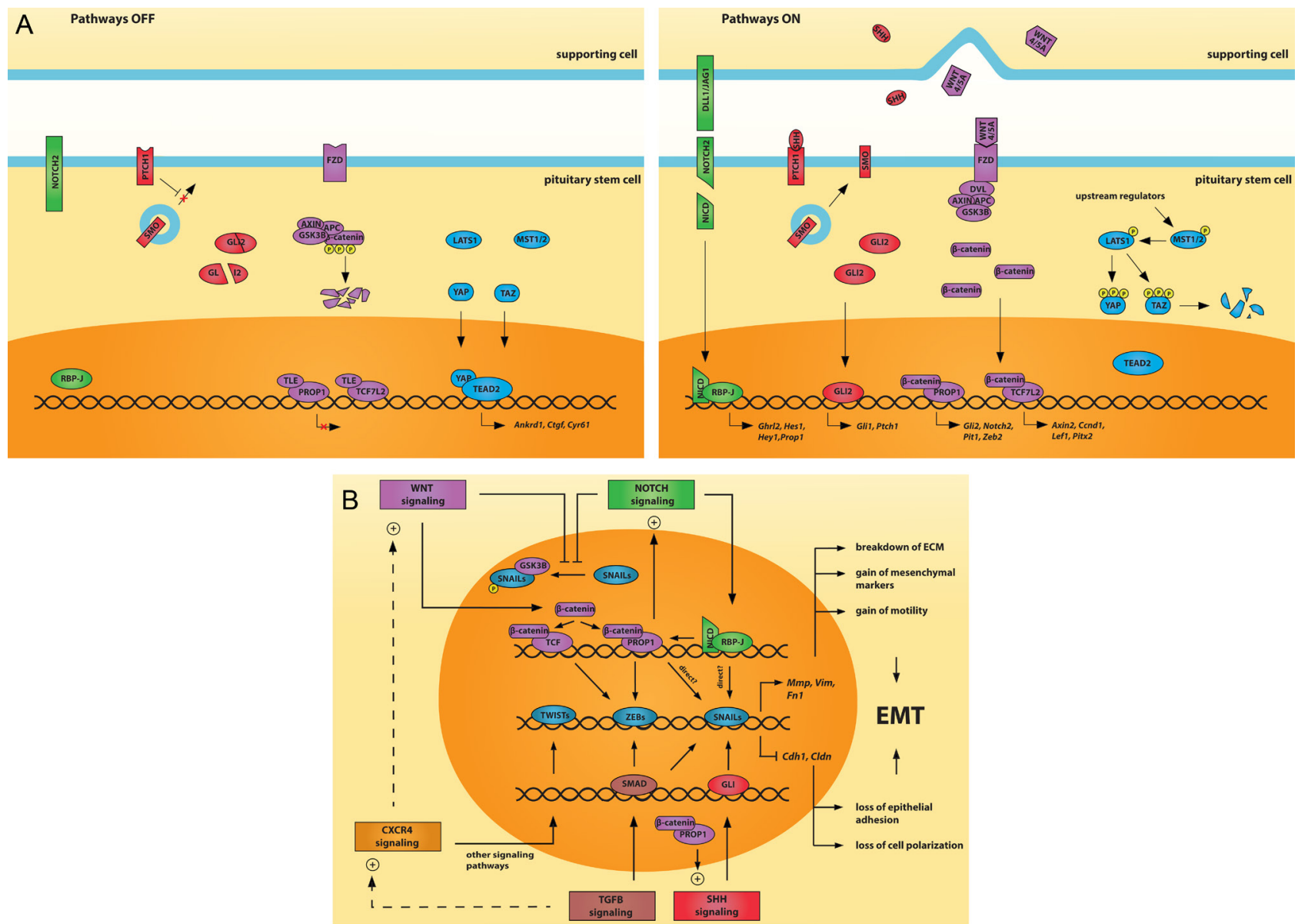

\section{Figure 1}

Overview of the signaling pathways potentially involved in pituitary stem cell regulation. (A) Schematic presentation of the putative pituitary stem cell niche, encompassing the stem cells and the stem cell-supporting cells. The NOTCH (green), SHH (red), WNT (purple) and Hippo (blue) pathways are shown in their 'off' (left) and 'on' status (right). Interaction of the NOTCH transmembrane receptor with DLL/JAG ligands on adjacent cells initiates cleavage of the Notch intracellular domain (NICD), which translocates to the nucleus to associate with the transcription factor RBP-J, thereby inducing expression of NOTCH target genes. Binding of SHH to PTCH receptor releases SMO from endocytic vesicles (light blue circle), preventing GLI degradation and thereby enabling GLI migration to the nucleus where it regulates SHH target gene expression. In the presence of WNT ligands, interaction with the FZD receptor inhibits degradation of $\beta$-catenin which then in the nucleus converts transcriptional repressors (e.g. TCF7L2) to activators or activates transcription by PROP1, resulting in WNT target gene expression. When Hippo signaling is 'on', a phosphorylation cascade involving the LATS and MST kinases is activated, leading to YAP/TAZ phosphorylation, thereby inhibiting downstream gene expression. DVL, Disheveled. For further details and abbreviations, see text. (B) Schematic model of the EMT network potentially unfolding in the pituitary stem cells. During EMT, epithelial markers (e.g. E-cadherin) are downregulated and mesenchymal markers (e.g. VIM) are upregulated. A central role is played by three families of transcription factors, i.e. TWISTs, ZEBs and SNAILs (blue), which repress transcription of the Cdh1 gene (coding for E-cadherin). Induction of matrix metalloprotease (Mmp) allows the eventual mesenchymal cell to move by breakdown of the surrounding extracellular matrix. EMT regulation involves a complex interplay between several pathways. TGFB signaling (brown) promotes transcription of Zebs and Snails through SMAD complexes and may enhance CXCR4 signaling (dashed line). CXCR4 signaling (orange) upregulates expression of Twists via ERK and PI3K/AKT signaling, leading to progression of EMT. CXCR4 may also activate WNT signaling (dashed line). The WNT pathway (purple) inhibits the phosphorylation of SNAILs by GSK3B, thereby increasing the stability of SNAILs, and can stimulate the expression of Zebs via TCF. The WNT-associated PROP1 increases expression of ZEBs and may also directly influence the expression of SNAI2. The involvement of PROP1 in EMT becomes even more elaborate by its stimulatory effect on the expression of NOTCH and SHH components, and its dependence on NOTCH activation. SHH signaling (red), through its transcription factor GLI1, enhances Snai1 expression which (further) induces EMT. NOTCH signaling (green) increases the stability of SNAI1 through disrupting GSK3B-SNAI1 interaction, and may also enhance the expression of Snails in a direct way. ECM, extracellular matrix. For further details and abbreviations, see text.

transcriptional repressors while allowing the neighboring cells to differentiate.

Also in the pituitary, NOTCH activity in the embryonic progenitor cells is essential for maintenance of the undifferentiated state (Zhu et al. 2006, 2015,
Nantie et al. 2014), with HES1 inhibiting progression toward hormonal cells (Zhu et al. 2006). In analogy, enforced persistent activation of NOTCH signaling in the more committed cells obstructs their final differentiation during embryogenesis (Zhu et al. 2006, 
Goldberg et al. 2011). NOTCH activity also affects the stem cells of the adult pituitary. In vitro stimulation by soluble JAG1 ligand triggers a proliferative expansion of the SC-SP (see above), whereas inhibition with DAPT shrinks the stem cell population (Chen et al. 2006, Tando et al. 2013).

Regarding the NOTCH pathway ligands, Dll1 is especially expressed around the cleft during pituitary embryogenesis (Raetzman et al. 2004, Zhu et al. 2006). Jag1 expression is comparable but largely extinguishes around the cleft from embryonic day (E) 12.5 onwards, while persisting in some parenchymal areas of the nascent AP (Zhu et al. 2006). In contrast, Dll3 is detected in developing corticotropes during embryogenesis and in melanotropes before and after birth (Hrabĕ de Angelis et al. 1997). Knockout of Dll3 did not affect pituitary cell specification, implying a non-essential or redundant role of Dll3 in the developing pituitary. Dll1 $1^{-/}$mice showed early embryonic death prior to pituitary development (Hrabě de Angelis et al. 1997). Conditional deletion specifically in the pituitary has not yet been performed. Prop $1^{\text {df/df }}$ embryonic pituitaries, displaying virtual absence of Notch2, showed higher Dll1 expression, which is in line with the principle of lateral inhibition within the NOTCH concept (Raetzman et al. 2004, Sprinzak et al. 2010).

In the adult resting pituitary, NOTCH ligands are higher expressed in the non-stem cell populations (Chen et al. 2009, Vankelecom 2010), also in agreement with the principle of lateral inhibition with $\mathrm{NOTCH}$ receptors and ligands being expressed in different (neighboring) cells, i.e. stem cells and niche-supportive cells, respectively (Fig. 1A). Additional identification of the ligand-exposing cells may further portray the pituitary stem cell niche(s). Remarkably, a recent study showed co-expression of NOTCH2 and JAG1 in the same pituitary stem cells (Batchuluun et al. 2017) which is not in line with the model of lateral inhibition. Moreover, in pituitary stem cell-activated conditions of neonatal maturation and somatotrope ablation injury (GH-Cre/ iDTR model), expression of the ligands Jag1 and/or Dll1 was found upregulated in the isolated stem cell populations (Gremeaux et al. 2012, Willems et al. 2016) (Table 1), suggesting that NOTCH activation is unfolding between the cells of the stem cell compartment in these activated states. In addition, the atypical Delta-like 1 homolog (DLK1) ligand, typically proposed to inhibit NOTCH signaling, is mainly expressed in somatotropes (Cheung et al. 2013), and elimination of these cells in the GH-Cre/iDTR mice through the DT-mediated somatotrope ablation may thus lead to a disinhibition of NOTCH signaling.
Regarding NOTCH receptor expression, Notch2 and Notch 3 were preferentially found in the SC-SP of the adult pituitary (Chen et al. 2009) (Fig. 1A and Table 1). Interestingly, the same NOTCH receptor subtypes are expressed in the embryonic pituitary progenitor cells, particularly around the cleft (Raetzman et al. 2004, Zhu et al. 2006), and Notch2 remains predominantly expressed around the cleft in the postnatal pituitary (Nantie et al. 2014). It is not known yet how NOTCH2 and NOTCH3 functionally overlap in the pituitary. In Prop1-

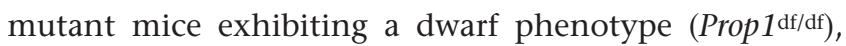
expression of NOTCH2 protein is absent, while Notch3 gene expression is not affected (Raetzman et al. 2004), positioning NOTCH2 but not NOTCH3 downstream of PROP1. Mice with Cre-mediated conditional knockout of Notch2 under the control of Foxg1, a factor expressed in RP cells at E9.5 (Wang et al. 2010), showed no obvious defects during pituitary embryonic development, suggesting that other NOTCH receptors like NOTCH3 may take over or provide sufficient NOTCH signaling during embryogenesis (Nantie et al. 2014). However, the Notch2 mutants showed a reduction in postnatal AP volume, together with a decrease in PIT1 lineage (in particular, $\mathrm{GH}^{+}$and $\mathrm{TSH}^{+}$) cells and an increase in $\mathrm{POMC}^{+}$cells. Moreover, $\mathrm{SOX}_{2}{ }^{+}$and $\mathrm{SOX}^{+}$cells were less abundant in the marginal zone of the Notch2 mutant pituitary. SOX2+ cell clusters were still present throughout the parenchyma and also at reduced abundance, whereas SOX9+ cell clusters were not observed anymore (Nantie et al. 2014), suggesting that maintenance or development of the stem cell population(s), and particular of the SOX9+ cells, is dependent on NOTCH signaling. The decreased number of postnatal stem cells may explain the reduced AP volume. Taken together, NOTCH2-mediated signaling is required for stem cell maintenance as well as appropriate differentiation (i.e. needed for the PIT1 lineage while repressing the corticotrope POMC lineage) during embryonic and postnatal pituitary development.

Taking out NOTCH activation by deleting the central mediator Rbp-J showed a profound effect on progenitor cell maintenance and differentiation in the embryonically nascent pituitary (Zhu et al. 2006, 2015). Conditional deletion of $R b p-J$ using Cre under control of Pitx 1 (already expressed in the oral ectoderm) diminished pituitary progenitor cell proliferation from E12.5 and resulted in a differentiation shift from PIT1 toward corticotrope lineage, again showing that proper NOTCH signaling is essential to induce the PIT1 lineage and suppress the corticotrope fate in the developing pituitary. Postnatal development could not be studied in these Pitx1-Cre/Rbp-f f $^{\mathrm{f} / \mathrm{l}}$ mice because of

Published by Bioscientifica Ltd. 
Table 1 Genes from regulatory pathways upregulated in the stem cell compartment of neonatal, adult, regenerating and tumorigenic pituitary.

\begin{tabular}{|c|c|c|c|c|c|}
\hline Pathwaya & $\begin{array}{l}\text { Neonatal pituitary } \\
(\text { SC-SP vs adult SC-SP) }\end{array}$ & $\begin{array}{l}\text { Adult pituitary } \\
\text { (SC-SP vs non-SC-SP)b }\end{array}$ & $\begin{array}{l}\text { Adult pituitary } \\
\text { (SOX2 } 2^{\text {GFP }} \text { vs SOX2 } 2^{\text {GFP- }} \\
\text { population) }\end{array}$ & $\begin{array}{l}\text { Regenerating } \\
\text { pituitary } \\
\text { (SC-SP after damage vs } \\
\text { control SC-SP)b }\end{array}$ & $\begin{array}{l}\text { Human pituitary } \\
\text { tumors } \\
\text { (SP vs non-SP)c }\end{array}$ \\
\hline \multicolumn{6}{|l|}{$\mathrm{NOTCH}$} \\
\hline Ligands & $D / 11, \underline{\operatorname{Jag} 1}$ & & & $D / / 1$ & $D L L 1, J A G 1$ \\
\hline Receptors & Notch2 & Notch2, Notch3 & Notch2 & Notch2 & NOTCH1, NOTCH2 \\
\hline Transcription factors & $R b p j$ & & & & \\
\hline $\begin{array}{l}\text { Transcriptional } \\
\text { targets }\end{array}$ & Hey1, Prop1 & Hey1, Hey2, Heyl & $\frac{\text { Grhl2 }}{\text { Heyl, }}, \underline{\text { Hey } 1}$, Hey2 & Hes1, Hey1 & $H E S 1, \underline{H E Y 2}, \underline{H E Y L}$ \\
\hline \multicolumn{6}{|l|}{ WNT } \\
\hline Ligands & $\frac{\text { Wnt2b }}{\text { Wnt5a }}$, & & $\begin{array}{l}\text { Wnt4, Wnt7b, } \\
\text { Wnt9a, Wnt10a }\end{array}$ & & WNT5A \\
\hline Receptors & 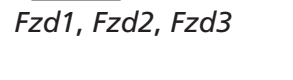 & $F z d 2, F z d 7$ & $\begin{array}{l}F z d 1, \underline{F z d 3}, \underline{F z d 4}, \\
F z d 6, \underline{F z d 7}\end{array}$ & Fzd6 & $F Z D 1, \underline{F Z D 10}$ \\
\hline RSPO/LGR & Rspo 1 & $\operatorname{Lgr} 5$ & Lgr4, Lgr5 & Rspo2 & LGR5 \\
\hline $\begin{array}{l}\text { Intracellular cascade } \\
\text { components }\end{array}$ & & & Csnk1a1 & Csnk1g2 & \\
\hline Transcription factors & 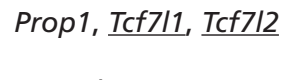 & Lef1, Tcf7 & Prop1, Tcf7, Tcf7/2 & Lef1 & $\begin{array}{l}\text { LEF1, TCF7L1, } \\
\text { TCF7L2 }\end{array}$ \\
\hline $\begin{array}{l}\text { Transcriptional } \\
\text { co-factors }\end{array}$ & Aes, $\underline{\text { Tle } 3}$ & & & Tle1 & TLE3 \\
\hline $\begin{array}{l}\text { Transcriptional } \\
\text { targets }\end{array}$ & $\underline{\text { Axin2}}, M y c$ & $\underline{\text { Lef1 }}$ & $\underline{\text { Cond1 }}, \underline{\text { Myc }}, \underline{\text { Pitx } 2}$ & Axin2, Lef1 & $L E F 1, M Y C$ \\
\hline $\begin{array}{l}\text { Non-canonical WNT } \\
\text { components }\end{array}$ & Ptk7 & & $\begin{array}{l}\text { Ankrd6, Celsr1, } \\
\underline{\text { Celsr2 }}, \underline{\text { Fzd3 }}, \text { Ror1, } \\
\underline{\text { Vangl2 }}\end{array}$ & & $P R I C K L E 1, R O R 1$ \\
\hline \multicolumn{6}{|l|}{ EMT } \\
\hline Ligands & $\underline{\mathrm{CxC} / 12}$ & $C x c / 12, \underline{T g f b 2}$ & $\underline{\operatorname{Tgfb2}}$ & $\begin{array}{c}C x c / 1, \frac{C x c 19}{,}, C_{x c l 12} \\
T g f b 1, T g f b 2\end{array}$ & $\frac{C X C L 1, C X C L 12,}{T G F B 1, T G F B 2}$ \\
\hline Receptors & & Cxcr4 & Tgfbr1 & Cxcr7, Tgfbr2 & $\begin{array}{l}\text { CXCR4, CXCR7, } \\
\text { TGFBR2 }\end{array}$ \\
\hline Transcription factors & $\frac{\text { Foxc1, Foxc2, }}{\frac{\text { Twist 1 }}{\text { Zeb2 }}, \text { Twist2 }}$ & $\begin{array}{l}\text { Foxc2, Prrx1, Prrx2, } \\
\text { Twist1, Twist2, } \\
\text { Zeb2 }\end{array}$ & Prrx 1, Prrx2 & Foxc2, Klf8, Snai1 & $\begin{array}{l}F O X C 1, S N A 11, \\
\text { SNAI2, ZEB1, } \\
\text { ZEB2 }\end{array}$ \\
\hline $\begin{array}{l}\text { Downstream } \\
\text { effectors }\end{array}$ & Mmp2, Fn1, Vim & $\begin{array}{l}\text { Acta2, Fos/1, Fosl2, } \\
\text { Mmp2, Mmp3 }\end{array}$ & Acta2, Fos/1 & $\begin{array}{c}\text { Fos/1, Mmp2, } \\
\text { Mmp3, Vim }\end{array}$ & $\begin{array}{l}\overline{A C T A 2}, \text { FN1, FOSL2, } \\
M M P 1, \underline{\text { VIM }}\end{array}$ \\
\hline \multicolumn{6}{|l|}{$\mathrm{SHH}$} \\
\hline Ligands & Hhip & Hhip & & & \\
\hline Receptors & Ptch1, Smo & & Ptch1, Smo & & \\
\hline Transcription factors & Gli1, Gli2, Gli3 & & & Gli1, Gli2 & GLI1 \\
\hline $\begin{array}{l}\text { Transcriptional } \\
\text { targets }\end{array}$ & Ptch1 & & Ptch1 & & PTCH1 \\
\hline \multicolumn{6}{|l|}{ Hippo } \\
\hline Upstream kinases & Lats1 & & $N f 2, \underline{W w C 1}$ & Lats2, Stk4 & LATS2 \\
\hline $\begin{array}{l}\text { Transcription (co-) } \\
\text { factors }\end{array}$ & $\underline{\text { Tead2 }}, \underline{\text { Yap1 }}$ & & & & $\underline{T E A D 4}, \underline{Y A P 1}$ \\
\hline $\begin{array}{l}\text { Transcriptional } \\
\text { targets }\end{array}$ & & & Cyr61, Ankrd1 & Ctgf, Cyr61 & CTGF, CYR61 \\
\hline \multicolumn{6}{|l|}{ FGF/EGF } \\
\hline Receptors & $\underline{\text { Egfr }}, \underline{\text { Fgfr1 }}, \underline{\text { Fgfr } 2}$ & Egfr, Fgfr1 & Egfr, Fgfr1, Fgfr2 & Egfr, Fgfr1 & $\underline{E G F R}, F G F R 1, F G F R 3$ \\
\hline
\end{tabular}

aSelection of genes at least 1.5-fold upregulated, as identified by microarray analyses in our previous studies (Chen et al. 2009, Vankelecom 2010, Gremeaux et al. 2012, Mertens et al. 2015, Willems et al. 2016) and from SOX2 eGFP RNA-sequencing data (B Cox, H Roose and H Vankelecom, unpublished observations). Underlined: genes $\geq 5$-fold upregulated. Bold: genes validated using other techniques in studies of our or other groups (see text). ${ }^{b} M o r e$ details on the definition of these populations can be found in Chen et al. (2009), Vankelecom (2010), Gremeaux et al. (2012) and Willems et al. (2016). In short, SC-SP represents the SP depleted from cells expressing stem cell antigen-1 (SCA1) at a high level; non-SC-SP refers to the remaining SP (SCA 1 high SP) and the MP. cMore details on the definition of these populations can be found in Mertens et al. (2015). In short, SP here stands for the SP depleted from CD31+ endothelial and CD45+ immune cells, and non-SP for the MP depleted from CD31+ endothelial and CD45+ immune cells.

http://joe.endocrinology-journals.org DOI: 10.1530/JOE-17-0083
๑) 2017 Society for Endocrinology Printed in Great Britain
Published by Bioscientifica Ltd 
perinatal lethality. Conditional deletion of $R b p-J$ using a Prop1-Cre driver resulted in a milder hormonal phenotype with timely formation of the PIT1 lineage (Zhu et al. 2015). PITX1 expression is initiated in the developing pituitary before PROP1 (E9.0 and E11.5, respectively), and the earlier blockade of NOTCH signaling may explain the more severe phenotype in the above described Pitx1-Cre/ Rbp-ft/fl mice (Olson et al. 2006, Zhu et al. 2006). Moreover, PROP1 expression failed to peak in Pitx1-Cre/Rbp-J fl/fl $^{\mathrm{f}}$ mice at E12.5 (Zhu et al. 2006), appointing Prop1 as a target gene of NOTCH signaling, which may further contribute to the fiercer phenotype as PROP1 deficiency is well known to result in combined pituitary hormone deficiency (Abrão et al. 2006). During embryogenesis, Prop1-Cre/ $R b p$ - fl/fl $^{\text {mice }}$ showed a reduction in proliferating SOX2+ cells, both in the developing AP and IL (Zhu et al. 2015). After birth, stem cells lining the cleft and parenchymal stem cell clusters were largely missing, as indicated by the absence of SOX2, SOX9, E-cadherin and PROP1 immunoreactivity (Zhu et al. 2015). Accordingly, sphere formation was largely reduced. This important impact of NOTCH signaling on pituitary stem cell functionality was further supported by the virtual abrogation of sphere formation when adult (wild-type) AP cells were treated with the NOTCH inhibitor DAPT. Of note, RBP-J is not only able to bind the promoters of Sox 2 and Prop 1 but also of genes encoding various transcriptional effectors of the WNT, Hippo and SHH pathways (Zhu et al. 2006, Li et al. 2012a, Nantie et al. 2014) (see below).

Among the other NOTCH downstream effectors, HES1 has been shown important to sustain proliferation of the RP progenitor cells by regulating cell cycle inhibitors and to suppress the expression of genes encoding prodifferentiation transcription factors like Mash1, Tbx19 and NeuroD1 (Zhu et al. 2006, Monahan et al. 2009). Hes1 knockout mice exhibit premature corticotrope differentiation, similar to Pitx1-Cre/Rbp-f $\mathrm{f}^{\mathrm{f} / \mathrm{fl}}$ mice. In contrast, the PIT1 lineage is properly induced in the Hes $1^{-/-}$animals, suggesting the involvement of dissimilar transcriptional targets of RBP-J (e.g. HES1 for corticotrope and PROP1 for PIT1 lineage) (Himes \& Raetzman 2009). In the postnatal pituitary, expression of both Hes1 and Hey 1 is detected in the cells lining the cleft (Nantie et al. 2014). In the stem cell population (SC-SP) of the adult pituitary, Hey1 seems to be the main NOTCH pathway target component (Chen et al. 2009) (Table 1), whereas Hes6, in general, involved in NOTCH-driven differentiation (Bae et al. 2000), is higher expressed in the non-SP 'main population' (MP) (Chen et al. 2006). Recently, grainyheadlike 2 (Grhl2) has been advanced as another direct NOTCH downstream target gene in the pituitary (Edwards et al. 2016). Its expression is mainly restricted to SOX2+ cells, both in the marginal zone and in the parenchyma. In agreement, we detected higher Grhl2 gene expression in pituitary SOX2 $2^{\text {eGFP+ }}$ stem cells as purified by FACS based on their Sox2-driven enhanced green fluorescent protein (eGFP) expression (Table 1). GHRL2 is also co-localized with the pituitary stem cell indicator E-cadherin and both markers concomitantly go down in Notch 2 conditional knockout mice (Edwards et al. 2016). In other tissues, GHRL2 has been found to induce the expression of $C d h 1$ (encoding E-cadherin) (Werth et al. 2010, Chen et al. 2016), which may explain their colocalization in pituitary stem cells. In return, E-cadherin is also needed for proper NOTCH signaling as inhibition of E-cadherin function using antibodies decreases the proportion of NOTCH2+ cells with HES1 immunopositivity (Batchuluun et al. 2017). Of note, another pathway with NOTCH-like juxtacrine makeup recently described in the pituitary stem cell niche is the ephrin-ephrin receptor system (Vankelecom 2010, Yoshida et al. 2014, Cheung et al. 2017). Together with $\mathrm{NOTCH}$, ephrin-ephrin receptor signaling may operate to manage the stem cell niche and prevent the niche cells from intermingling with other cells (Batlle et al. 2002).

Taken together, the summarized findings support the existence of the NOTCH pathway as regulatory system contained within the pituitary stem cell niche(s), plausibly acting in a Janus 'two-headed' manner to govern on the one side stem/progenitor cell proliferation and maintenance, and on the other side, differentiation into particular cell lineages. So far, this functional role has particularly been studied in the embryonic pituitary. Although expression data point to a same picture in the postnatal gland, thorough functional validation is still awaited.

\section{WNT pathway: broad pituitary regulatory system with tentacles twisting in and out the stem cell compartment?}

The WNT pathway represents another regulatory system essential for development, already impacting on the earliest phases following egg fertilization. The pathway is composed of WNT ligands that bind to Frizzled (FZD) receptors, often in complex with low-density lipoprotein receptor-related protein (LRP), RAR-related orphan receptor (ROR) and/or protein tyrosine kinase 7 (PTK7), which all function as co-receptors (Niehrs 2012). In contrast to NOTCH ligands, WNTs are secreted although

Published by Bioscientifica Ltd. 
their action remains limited to short distances (Farin et al. 2016). In the absence of WNT ligand/receptor interaction, the downstream effector $\beta$-catenin is phosphorylated by a molecular complex containing the catalytic subunit glycogen synthase kinase-3 $\beta$ (GSK3B) and other proteins including AXIN, adenomatosis polyposis coli (APC) and casein kinase 1 (CK1) (Fig. 1A). $\beta$-catenin phosphorylation targets the protein for ubiquitination by binding to $\beta$-transducin repeat containing protein (BTrCP) and subsequent degradation by the proteasome. However, when WNT ligands bind to FZD receptors, $\beta$-catenin phosphorylation and degradation are inhibited, allowing the protein to accumulate and translocate to the nucleus (Fig. 1A). Classically, stabilization of $\beta$-catenin has been attributed to the recruitment of several components of the destruction complex to the WNT/receptor configuration, causing a disintegration of the destruction complex. More recently, it has been suggested that ubiquitination of $\beta$-catenin is inhibited because of the destruction complex indeed moving to the membrane, however, remaining intact (Clevers \& Nusse 2012, Li et al. 2012b) (Fig. 1A). After translocation to the nucleus, $\beta$-catenin converts several transcriptional repressors, such as T-cell factor (TCF) 7 (previously called TCF1), TCF7-like 1 (TCF7L1, previously called TCF3), TCF7L2 (previously called TCF4) and lymphoid enhancer factor (LEF) 1, to activators by competing with corepressors like amino-terminal enhancer of split (AES) and transducin-like enhancer of split (TLE). The subsequent expression of downstream target genes like Axin2, Myc, Lef1 and CyclinD1 is often used as readout for the activation status of this canonical WNT/ $\beta$-catenin pathway (Andoniadou et al. 2013, Chambers et al. 2013).

In addition, WNT-to-FZD binding can also influence other downstream signaling routes, together referred to as non-canonical WNT pathways. Best defined are the planar cell polarity (PCP) and the WNT-Ca ${ }^{2+}$ pathways. PCP involves small GTPases such as RAS homolog family member A (RHOA), and c-JUN N-terminal kinase (JNK), which can directly affect the cytoskeleton or activate transcription factors such as c-JUN and activating transcription factor 2 (ATF2) (Niehrs 2012). The WNT-Ca ${ }^{2+}$ pathway stimulates the production of inositol-1,4,5triphosphate, leading to $\mathrm{Ca}^{2+}$ release from intracellular stores into the cytoplasm and activation of $\mathrm{Ca}^{2+-}$-responsive effectors such as calcineurin, $\mathrm{Ca}^{2+} / \mathrm{calm}^{2}$ odulin-dependent protein kinase II and protein kinase C (Niehrs 2012).

Last but not least, WNT activation is boosted by the R-spondin (RSPO)/leucine-rich repeat-containing G-protein-coupled receptor (LGR) system. Binding of RSPO1-4 ligands to LGR4-6 receptors inhibits the degradation of FZD receptors, thereby amplifying both canonical and non-canonical WNT signaling (Glinka et al. 2011, Hao et al. 2012). Although specific WNT ligands and receptors have been assigned to canonical or noncanonical signaling, it is rather the particular combination of ligand, receptor and co-receptor, which determines this nature in a context-dependent way (Niehrs 2012, Fu et al. 2016).

Various WNT ligands and FZD receptors have been detected in the pituitary depending on the stage of development (Potok et al. 2008). WNT4 and WNT5A, mainly assigned to the non-canonical WNT pathway but also involved in some canonical actions (Potok et al. 2008, Bernardi et al. 2011, Fu et al. 2016), play important roles during pituitary embryogenesis. WNT4 is detected adjacent to the cleft during embryogenesis and is required for differentiation of the PIT1 lineage, suggesting a role for WNT4 in activating PROP1 (Treier et al. 1998, Potok et al. 2008). WNT5A is faintly expressed in RP while its prime expression site is within the neighboring ventral diencephalon. Knockout of Wnt5a leads to a dysmorphic gland, but endocrine cell specification is almost not affected (Cha et al. 2004, Potok et al. 2008). FZD2 is also expressed in the RP progenitor cells (E12.5), which renders these cells sensitive to the prevailing WNT ligands (Douglas et al. 2001, Potok et al. 2008). Wnt4 and $\mathrm{Fzd} 2$ continue to be upregulated in the neonatal stem cell compartment as compared to the adult SC-SP, which may be associated with the activated status of these cells during neonatal maturation (Gremeaux et al. 2012) (Table 1). In the adult gland, Fzd2 remains higher expressed in the SC-SP as compared to the non-stem cell populations (Chen et al. 2009, Vankelecom 2010) (Table 1). In the adult pituitary's SOX2 ${ }^{\mathrm{eGFP}}$ stem cells, we found upregulated expression of Wnt4 (and 7b, 9a, 10a) and Fzd3 (and 1, 4, 6, 7 but not Fzd2) when compared to the GFP- cells (Table 1). Interestingly, Lgr4 and Lgr5 are also upregulated in the pituitary stem cell compartment of adult mice (Chen et al. 2009) (Table 1). These findings are in agreement with the observation that LGR proteins mark adult stem cells in a variety of epithelial tissues (Barker et al. 2007, 2010, Ren et al. 2014). Moreover, LGR4driven $\beta$-galactosidase expression has been detected in the adult gland before pituitary stem cells were identified, with LGR4lacz+ cells almost exclusively found around the cleft (Van Schoore et al. 2005). The LGR ligand Rspo2 is upregulated in the pituitary SC-SP in response to damage (Willems et al. 2016) and Rspo1 is higher expressed in the SC-SP during neonatal maturation (Gremeaux et al. 2012)

Published by Bioscientifica Ltd 
(Table 1), thereby suggesting that WNT signaling in the pituitary stem cells is further magnified by RSPO/LGR activation during these activation conditions. Together, it appears that both ligands and receptors of the WNT pathway, at least certain members, are preferentially found within the pituitary stem cell compartment. Yet, WNT5A immunopositivity has been reported to occur throughout the adult pituitary parenchyma (Treier et al. 1998, Potok et al. 2008), suggesting a broader territory of unfolding of the WNT pathway.

Regarding downstream components of WNT signaling, several factors have been detected in the pituitary. The WNT pathway corepressors Aes and TLE1 are expressed in the nascent pituitary gland but are extinguished by E16.5 (Dasen et al. 2001, Brinkmeier et al. 2003). HESX1, an early (E11.5) marker and essential regulator of pituitary development, forms a complex with TLE1 in the RP progenitor cells and is expressed in a mutually exclusive manner with PROP1 (Dasen et al. 2001, Carvalho et al. 2010). WNT pathway activation results in nuclear $\beta$-catenin that forms a complex with PROP1 (E12.5-13.5), which represses Hesx1 transcription, being essential for pituitary development to progress, and induces the expression of differentiation-driving factors like Pou1f1/Pit1 (Dasen et al. 2001, Olson et al. 2006, Pérez Millán et al. 2016) (Fig. 1A). In agreement, conditional deletion of the Ctnnb1 gene (encoding $\beta$-catenin) leads to the absence of PIT1 expression and reproduces the phenotype of the Prop1-mutant (Prop1 ${ }^{d f / d f}$ ) mouse, thereby underscoring the importance of the $\beta$-catenin/PROP1 interaction for pituitary development to advance (Andersen et al. 1995, Olson et al. 2006). In accordance, activation of WNT signaling by inhibiting $\beta$-catenin degradation using GSK3B inhibitors promotes the (in vitro) differentiation of pituitary progenitor cells toward hormone-expressing cells (Suga et al. 2011, Yoshida et al. 2016a).

While the most important $\beta$-catenin actions during pituitary embryogenesis may be mediated by PROP1 activation, additional $\beta$-catenin-responsive transcription factors are also detected in the developing pituitary like PITX2, LEF1, TCF7L1 and TCF7L2. PITX2 plays a crucial role in pituitary embryogenesis and is expressed in the oral ectoderm already before RP formation (Gage et al. 1999, Suh et al. 2002). PITX2 is also dependent on complexing with $\beta$-catenin for its function (Kioussi et al. 2002). LEF1 is temporally detected in the developing pituitary at E9.0, and reappears at E13.5, but no aberrant pituitary phenotype was observed in Lef1-/ mice during embryonic development (Olson et al. 2006). In contrast, conditional Tcf7l1 knockout affects pituitary development, but coexisting effects at the level of the ventral diencephalon complicate the interpretation of the pituitary phenotype (Gaston-Massuet et al. 2016). TCF7L2 may be involved in the repression of Prop1 in embryonic pituitary progenitor cells (Brinkmeier et al. 2003, 2007). Several of these components of the WNT transcriptional machinery remain upregulated in the pituitary stem cell compartment during the neonatal maturation phase (Prop1, Tcf7l1, Tcf7l2) as well as during adult life (Lef1, Prop1, Tcf7, Tcf7l2) (Chen et al. 2009, Garcia-Lavandeira et al. 2009, Vankelecom 2010, Gremeaux et al. 2012) (Table 1). In contrast, in addition to WNT5A (Treier et al. 1998, Potok et al. 2008; see above), TCF7L2 and nuclear $\beta$-catenin immunostaining have been reported to exist throughout the adult gland (Brinkmeier et al. 2007), supportive of WNT signaling also outside the stem cell compartment. In the stem cell niches of the adult resting pituitary, $\beta$-catenin was detected as a membranous signal (Garcia-Lavandeira et al. 2009), suggesting rather a role in epithelial cell-cell adhesion by connecting the membranous E-cadherin (as also found in the stem cells) to the cytoskeleton (El-Bahrawy \& Pignatelli 1998). Along the same line, SOX2 is able to sequester $\beta$-catenin, thus creating a higher threshold for canonical WNT/ $\beta$-catenin signaling to occur within the pituitary stem cells (Kelberman et al. 2008, Alatzoglou et al. 2011). On the other hand, the $\beta$-catenin chaperone PROP1 is primarily detected in the SOX2+ (stem) cells in the adult gland, although its exact location is still debated, being either in the parenchymal $\mathrm{SOX}^{+}{ }^{+}$cell clusters (as reported in rat) (Yoshida et al. 2011,2014 ) or in the SOX2+ cells lining the cleft (as reported in mouse) (Garcia-Lavandeira et al. 2009). The downstream WNT target genes CyclinD1 (Ccnd1), Lef1, Myc and Pitx2 are upregulated in the adult pituitary stem cell compartment (Vankelecom 2010) (Table 1). Interestingly, Axin2 is upregulated in the SC-SP of the neonatal pituitary and of the regenerating adult gland after somatotrope ablation injury (Gremeaux et al. 2012, Willems et al. 2016) (Table 1), pointing to (further) canonical WNT activation in the stem cell compartment during the vivid early-postnatal growth phase and upon damage. This specific activation may be needed for stem cell expansion, which is in line with the role of WNT signaling in many other tissues (Sato et al. 2009). In the context of the somatotrope regeneration process, WNT activation may further be needed for stem cell differentiation toward the PIT1 lineage by derepressing PROP1 function.

Published by Bioscientifica Ltd. 
In addition to this mostly canonical perspective on pituitary WNT signaling, non-canonical aspects should also be considered, including a potential PCPlike organization of the marginal zone as suggested by polarized staining patterns (e.g. of GFRA2 and $\beta$-catenin, see Garcia-Lavandeira et al. 2009). Moreover, several noncanonical components (e.g. Ankrd6, Celsr1, Fzd3) are found upregulated in the adult pituitary SOX2 $2^{\text {eGFP+ }}$ stem cell population (Table 1).

Taken together, WNT signaling plays an important role during pituitary embryogenesis with impact on the early progenitor cells, both at the level of their maintenance and their differentiation. The presence of multiple components in the pituitary after birth also points to WNT activity in the postnatal gland. WNT signaling does not seem to be restricted to the stem cell compartment, but occurring all over the gland in the basal, homeostatic situation. Its activity may be boosted in the stem cells when these cells are brought in activation modus for neonatal maturation or regeneration. WNT signals may sprout from the endocrine parenchymal cells, but may reversely also deploy from the stem cells toward the endocrine cells in a forward signaling manner, together suggesting a complex interplay between endocrine AP cells and stem cells regarding WNT/LGR signaling. Taken together, WNT appears to 'blow' softly all over the postnatal '(g)land' under basal conditions, but may become more 'stormy' in the stem cell compartment in the damage- and neonatally activated pituitary.

\section{EMT: preparing the pituitary stem cells for a stroll?}

Epithelial-mesenchymal transition (EMT) is a highly conserved cellular process in which epithelial cells, typically polarized in apical-basal direction and tightly linked to the basal membrane, are converted into motile non-polarized mesenchymal cells. The epithelial cells gradually lose cell-cell adhesion and polarization to progressively acquire mesenchymal properties, including the ability of invasion and migration. EMT, together with the reverse process of mesenchymal-epithelial transition, plays a pivotal role in the formation of organs and tissues during embryonic development, in wound repair and in cancer pathogenesis and progression.

Central facets of the EMT process are the (gradual) disappearance of the cell-cell adhesion protein 'epithelial cadherin' (E-cadherin) and the emergence of mesenchymal markers like vimentin (VIM) and fibronectin (FN) (Fig. 1B).
Several factors repress the transcription of the $C d h 1$ gene, encoding for E-cadherin. SNAI1 (also known as SNAIL1), a zinc finger transcription factor, downregulates $C d h 1$ expression by direct interaction with the $C d h 1$ promoter. The EMT-inducing activity of other transcriptional repressors such as SNAI2 (also known as SLUG), zinc finger E-box-binding homeobox 1 (ZEB1), ZEB2 (also known as SIP1), TCF3 and Krüppel-like factor 8 (KLF8) relies not only on direct inhibition of Cdh1 gene transcription but also on simultaneous repression of genes encoding other junctional proteins such as claudins (CLDN) and desmosomal junction components (e.g. desmoglein, desmoplakin) (Fig. 1B). TWIST1 (Yang et al. 2004), the embryonic transcription factor forkhead box protein C1 (FOXC1) and FOXC2 (Mani et al. 2007), transcription factor 4 (TCF4, also known as E2-2) (Sobrado et al. 2009) and Goosecoid (Hartwell et al. 2006) seem to trigger EMT without binding directly to the $C d h 1$ promoter, but detailed mechanisms remain unclear. Increased expression of proteases like matrix metallopeptidase 3 (MMP3) promotes EMT, not only by clearing the way for cell movement but also by modulating signal transduction leading to the stabilization of EMT (De Craene \& Berx 2013) (Fig. 1B).

EMT is also closely intertwined with the fundamental signaling networks of WNT, NOTCH, SHH and transforming growth factor- $\beta$ (TGFB) (Fig. 1B). Both WNT and NOTCH signaling can prevent phosphorylation of SNAI1 and SNAI2 (collectively referred to as SNAILs) by GSK3B, thereby increasing their stability and availability for the EMT process (Lamouille et al. 2014, Frías et al. 2015). Moreover, WNT signaling activates the transcription of Zeb1 and Zeb2 (collectively referred to as $Z e b s)$, while NOTCH activation can trigger the expression of SNAILs depending on the cellular context (Xu et al. 2009a, Lamouille et al. 2014) (Fig. 1B). In addition, the transcription factor PROP1, which promotes EMT (see below), relies on both NOTCH and WNT signaling for its expression and activation (as mentioned previously; Olson et al. 2006, Zhu et al. 2006, Pérez Millán et al. 2016). TGFB signaling stimulates the expression of Zebs and Snails by the activation of SMAD transcriptional complexes (Lamouille et al. 2014) (Fig. 1B). SHH pathway activation can also promote EMT by increasing Snai1 expression (Lamouille et al. 2014). Another important regulator of EMT-associated cell migration is the chemokine (C-X-C motif) receptor 4 (CXCR4) and its ligand stromal cell-derived factor 1 (SDF1), also called CXCL12. This signaling system positively influences the expression of Twist1 and Twist2 (collectively referred to as

Published by Bioscientifica Ltd. 
Twists), mediated by activation of the extracellular signalregulated kinase (ERK) and phosphoinositide 3-kinase/ thymoma viral proto-oncogene (PI3K/AKT) pathways (Yao et al. 2016). Moreover, other reports show a positive influence of the TGFB pathway on CXCR4 signaling, while the CXCR4 pathway can enhance WNT signaling (Bertran et al. 2009) (Fig. 1B).

During pituitary embryogenesis, the RP progenitor cells that are located around the cleft need not only to proliferate but also to colonize the ventral region in order to grow the developing anterior lobe. The observed morphological changes of the progenitor cells, from tightly packed columnar-type cells into more loosely distributed cells, are reminiscent of an EMT program. PROP1 has regularly been proposed to regulate the progenitor cell migration process during pituitary organogenesis (Ward et al. 2005, Himes \& Raetzman 2009). Prop $1^{\mathrm{df} / \mathrm{df}}$ mice exhibit a dysmorphic embryonic pituitary with enlarged progenitor zone and small ventral part, purportedly due to a failure of progenitor cells to leave the proliferative zone in the absence of PROP1. In agreement, Prop $1^{\mathrm{df} / \mathrm{df}}$ mice lose SLUG (SNAI2) expression in most parts of the embryonic pituitary, which may explain the absence of EMT and its accompanying motility (Himes \& Raetzman 2009). The resulting accumulation of progenitor cells finally leads to increased apoptosis and pituitary hypoplasia. Also human patients with mutations in PROP1 eventually show dysmorphic, hypoplastic pituitaries with underdevelopment of one or multiple hormone-producing cells, leading to (combined) pituitary hormone deficiency (Abrão et al. 2006). PROP1 signal, being co-expressed with SOX2, does not only peak during early embryogenesis but also during the earlypostnatal wave of pituitary growth (Pérez Millán et al. 2016), supporting the idea that stem cell EMT also plays a role during this transient neonatal growth phase. In accordance, genes involved in EMT are found to be more prominently expressed in the neonatal pituitary SC-SP when compared to the adult SC-SP (e.g. Fn1, Mmp2, Prop1, Twist1, Twist2, Vim, Zeb2) (Gremeaux et al. 2012) (Table 1). The link between PROP1 and EMT during early-postnatal life is further clear from the downregulation of EMTrelated genes (such as Zeb2, Cxcl12 and Mmps) and the upregulation of epithelial genes (like Cdh1 and Cldn23) in adherent colonies formed in vitro from pituitary (stem) cells of 2-week-old Prop1 ${ }^{\text {df/df }}$ mice (Pérez Millán et al. 2016). PROP1 directly regulates $Z e b 2$ transcription by binding to its promoter, and Zeb2 knockdown blocks EMT as tested in wild-type pituitary-adherent colonies (Pérez Millán et al. 2016). In addition, components of the major signaling pathways $(\mathrm{NOTCH}, \mathrm{WNT}$, SHH and TGFB), fundamentally also linked to EMT (Fig. 1B), are differently expressed in the absence of PROP1, implying a central role for PROP1 in their regulation. Among others, PROP1 directly binds to the promoter of Notch2 and of the SHH mediator Gli2 (for SHH pathway, see below) (Pérez Millán et al. 2016) (Fig. 1B). It should be noted that expression of the mesenchymal marker N-cadherin did not change between wild type and Prop 1 df/df pituitary colonies (Pérez Millán et al. 2016), suggestive of a partial but not complete EMT that is unfolding (Leroy \& Mostov 2007, Savagner 2010). Cell cycle regulators (like CyclinD1 and CyclinE) are also lower expressed in the embryonic and neonatal pituitary of Prop $1^{\text {df/df }}$ mutant vs wild-type mice, proposing that PROP1 not only regulates the exit process of the stem/progenitor cells from the niche, but also their proliferation during the growth phase (Pérez Millán et al. 2016).

EMT expression characteristics remain present in the stem cell compartment of the adult gland; EMT-associated markers (e.g. Twist1, Twist2, Zeb2) are upregulated in the SC-SP when compared to the MP (Chen et al. 2009, Vankelecom 2010) (Table 1). Moreover, pairedrelated homeobox (Prrx) 1 and Prrx2, mainly known as mesenchymal markers and potentially involved in EMT (Ocaña et al. 2012), are also upregulated in the adult pituitary stem cell population (SC-SP and SOX2 $2^{\text {eGFP+ }}$ cell compartment) (Chen et al. 2009, Vankelecom 2010) (Table 1). PRRX1 is expressed in SOX2+ cells of the embryonic and adult (rat) pituitary and in a subset of all hormonal cell types in the adult pituitary (as analyzed at P30) (Susa et al. 2012). In contrast, PRRX2 only emerges after birth from P30 in a subset of the SOX2+ cells (Higuchi et al. 2014). Another mesenchymal marker, VIM, is found co-localized with coxsackie and adenovirus receptor (CAR) in some cells just beneath the marginal cell layer, particularly at neonatal age (Chen et al. 2013). CAR has been identified as an additional marker of the (rat) pituitary stem cells in the marginal zone as well as the parenchymal clusters throughout life (Chen et al. 2013). The $\mathrm{VIM}^{+} / \mathrm{CAR}^{+}$cells observed at neonatal age may represent the transitional state of the stem cells undergoing EMT and preparing to move (Yoshida et al. 2016b). Intriguingly, CAR is typically present at the apical side of the marginal zone cells, whereas a multicellular layer of 'depolarized' CAR+ cells is observed in the marginal zone during the neonatal maturation phase (Chen et al. 2013). Moreover, nestin ${ }^{+}$cells from the postnatal (rat) AP start to express mesenchymal markers (like VIM) and to adopt migratory activity when seeded in culture, further

Published by Bioscientifica Ltd. 
linking pituitary stem cells to EMT (Krylyshkina et al. 2005). Together, the data described previously support the idea that (partial) EMT is involved in pituitary stem cell regulation, in particular in migration toward the 'point of interest' during or after which the cells differentiate. Moreover, upregulation of EMT-associated genes (such as Cxcl12, Mmp2, Mmp3, Snai1, Tgfb2, Vim) has been found in the reacting SC-SP of the regenerating pituitary (Willems et al. 2016) (Table 1), likely needed to fulfill the increased demand for hormonal (in this case, $\mathrm{GH}^{+}$) cells.

In addition to epithelial (stem) cells adopting a mesenchymal state through (partial) EMT, authentic mesenchymal cells may also be present in the stem cell niche, functioning as stem cell-supporting cells (as found in niches of many tissues). A vimentin ${ }^{+}$layer of cells has been observed adjacent to the marginal zone in the postnatal rat and mouse pituitary (Krylyshkina et al. 2005, Garcia-Lavandeira et al. 2009, Vaca et al. 2016). However, these cells may also represent stem cells that have undergone EMT and have started to move (as described in the previous paragraph). The exact functional position, being either differentiating stem cells, stem cell-supportive cells or both, still has to be clarified.

Taken together, EMT appears involved in pituitary stem cell regulation not only during the embryonic phase, but also in postnatal life during neonatal maturation, adult homeostasis and regeneration in response to injury.

\section{Sonic Hedgehog: regulator of adult pituitary stem cell proliferation?}

The Hedgehog $(\mathrm{HH})$ pathway is one of the protagonists of embryogenesis and crucial for the development of many organs. Mutations in this pathway cause severe developmental disorders (like holoprosencephaly; Cohen 2010). The pathway includes the secreted ligands Indian Hedgehog, Desert Hedgehog and SHH, which all bind to Patched (PTCH) receptors in the cell membrane. PTCH exerts inhibitory activity on SHH signaling by holding the smoothened (SMO) receptor imprisoned in endocytic vesicles (Fig. 1A). Binding of SHH to PTCH releases SMO, which inhibits the cytosolic degradation of the $\mathrm{SHH}$ downstream effectors GLI1-3, otherwise exerted by a complex including protein kinase A (PKA), GSK3B and CK1 (Tempé et al. 2006, Cohen 2010, Yavropoulou et al. 2015a). These GLI transcription factors are then able to enter the nucleus and activate (GLI1 and GLI2) or repress (GLI3) different transcriptional targets. Gli1 and Ptch1 themselves are targets of the SHH pathway (Fig. 1A), but also ligands of the BMP, FGF and WNT pathway can be induced by the GLI factors (Mullor et al. 2001, Cohen 2010, Wang et al. 2010, Yavropoulou et al. 2015a).

During embryogenesis, SHH that is first expressed throughout the oral ectoderm, becomes excluded from the invaginating part that forms RP, while the adjacent zones and the ventral diencephalon keep producing $\mathrm{SHH}$ (Treier et al. 2001). The progenitor cells constituting RP express Ptch1, hence being receptive to these incoming SHH signals (Treier et al. 2001). Inhibition of the SHH pathway interferes with the separation of RP from the oral ectoderm and results in a severely hypoplastic pituitary with delayed PROP1 expression (Treier et al. 2001). GLI2 turns out to be a key player in pituitary embryogenesis since patients with GLI2 mutation develop severe hypopituitarism (Bear et al. 2014, Arnhold et al. 2015). From mouse studies, it is known that GLI2 ensures proper proliferation of the RP progenitor cells, although also indirect effects originating from the ventral diencephalon are playing in this phenotype (Wang et al. 2010). Together, SHH signaling is essential for pituitary specification by driving the earliest stages of pituitary development and regulating the early progenitor cells. In agreement, development of pituitary-phenotypical cells from pluripotent stem cells invariably requires activation of the SHH pathway (Suga et al. 2011, Dincer et al. 2013, Ozone et al. 2016, Zimmer et al. 2016).

Addition of the SMO inhibitor cyclopamine to adult mouse pituitaries cultured as explants was reported to reduce levels of the downstream target Gli1, indicating that SHH is also basally active in the adult pituitary (Pyczek et al. 2016). The pathway receptors and/or targets Ptch1 and Smo are detected in the adult pituitary, particularly in the stem cell compartment (Chen et al. 2009, Vankelecom 2010) (Table 1). Moreover, expression of several SHH pathway components, including Gli2, Smo and the target genes Gli1 and Ptch1, are upregulated in the neonatal SC-SP and/or the adult SC-SP after pituitary injury, supportive of the pathway's association with the activated state of the stem cells in these conditions (Gremeaux et al. 2012, Willems et al. 2016) (Table 1).

Conditional, tamoxifen-induced knockout of Ptch during adulthood (using a ubiquitously expressed CreERT transgene), leading to the activation of the pathway in SMO-expressing cells of all organs, resulted in GLI1 detection in both pituitary stem cells and more committed hormonal cells, and in increased proliferation (as probed by BrdU incorporation) of the SOX2+/SOX9+ stem cells. The findings suggest that the SHH pathway regulates adult pituitary stem cell proliferation (Pyczek et al. 2016).

Published by Bioscientifica Ltd 
However, there are some caveats to this recent study. BrdU incorporation was analyzed in vitro using pituitary explants. The explants from normal adult pituitaries showed a very high proportion of $\mathrm{BrdU}^{+}$cells within the $\mathrm{SOX}_{2}{ }^{+}$and $\mathrm{SOX}^{+}$cell population (around 20\%) even after only $48 \mathrm{~h}$ of BrdU addition, which is in clear contrast with the quiescent state of these cells as observed in vivo by several groups (being in line with the very low turnover rate of the adult gland; Garcia-Lavandeira et al. 2009, Fu et al. 2012, Andoniadou et al. 2013, Rizzoti et al. 2013, Zhu et al. 2015). Ptch deletion was ubiquitously induced, which affected the animal's health and restricted analysis to a limited period (no longer than 2 weeks after deletion). In addition, ubiquitous deletion likely leads to indirect effects since the SHH pathway is also active in neighboring structures of the pituitary like the hypothalamus. Pituitary-specific deletion is needed for more compelling conclusions here.

Together, the SHH pathway appears active in the postnatal pituitary stem cells and may regulate their proliferation although more data are needed to convincingly support this picture.

\section{Hippo pathway: a new player in pituitary stem cell regulation?}

Following the observation of tissue overgrowth in Hippo-/Drosophila (Harvey et al. 2003, Udan et al. 2003, Wu et al. 2003) and similar findings in mammals (Dong et al. 2007, Lu et al. 2010, Heallen et al. 2011), the Hippo pathway has been advanced as a key regulator of organ growth and size. To exert this regulation, the pathway integrates several upstream inputs, such as scaffolding proteins forming activation complexes in close proximity to cell junctions (rendering Hippo sensitive to cell-cell contacts and cell polarity); signals from extracellular matrix and cytoskeleton and mechanical tension (reviewed in Yu \& Guan 2013, Johnson \& Halder 2014, Sun \& Irvine 2016). The core of the mammalian Hippo signaling network comprises the kinases mammalian STE20-like protein kinase 1 (MST1), MST2, large tumor suppressor homolog 1 (LATS1) and LATS2 (Fig. 1A). The kinases are involved in a cascade ultimately phosphorylating yes-associated protein (YAP) and transcriptional co-activator with PDZbinding motif (TAZ), thereby marking these proteins for cytoplasmic retention and proteasomal degradation. When Hippo signaling is inactive, YAP and TAZ are not degraded and function as transcriptional co-activators that form complexes with TEA domain-containing sequencespecific transcription factors (TEAD), resulting in the expression of target genes that promote cell proliferation and survival such as connective tissue growth factor (Ctgf) and cysteine-rich angiogenic inducer 61 (Cyr61) (Johnson \& Halder 2014) (Fig. 1A). When the Hippo pathway is activated, YAP and TAZ are degraded and their target gene expression stops, resulting in a halt of cell proliferation and start of differentiation and/or apoptosis. This way, the Hippo pathway controls the size of organs during development. In addition, Hippo signaling has recently also been identified in the regulation of tissue stem cells (reviewed in Yu \& Guan 2013, Johnson \& Halder 2014), cells reasonably involved in the processes of organ growth. Genetic deletion of the YAP/TAZ-phosphorylating Mst1 and Mst2 leads to the increased emergence of liver stem cells (so-called oval cells) (Lu et al. 2010). Moreover, transient YAP induction results in de-differentiation of various tissue cells into proliferating cells with stem/ progenitor cell characteristics (Panciera et al. 2016). The Hippo network has also been implicated in tissue regeneration. Genetically enhanced YAP/TAZ activity in the adult heart stimulates cardiac regeneration after myocardial infarction (Heallen et al. 2013, Xin et al. 2013). In the intestine, YAP was found indispensable for regeneration of the epithelium by the intestinal stem cells after irradiation (Gregorieff et al. 2015).

The Hippo pathway has only recently been explored in embryonic and adult pituitary (Lodge et al. 2016, Willems et al. 2016). Expression of Mst1, Mst2 and Lats1 (but not Lats2) was detected during the entire period of pituitary embryonic development (Lodge et al. 2016). Tead2 and Yap1 were found highly expressed in the embryonic progenitor cell region and nuclear localization of YAP1 and TAZ was observed in RP. These data point to a role of the Hippo pathway in pituitary embryogenesis, likely concentrated in the progenitor cells. Also in the postnatal (3-week-old) pituitary, nuclear localization of YAP1 and TAZ was observed in the SOX2+ stem cell niche, and some signals were found scattered in the parenchyma (Lodge et al. 2016). As SOX2 has been suggested to exert a stimulatory effect on YAP/TAZ activity in other tissues, directly by promoting Yap1 gene transcription (Seo et al. 2013) and indirectly by repressing the Hippo pathway activators neurofibromin $2(\mathrm{Nf2})$ and WW domaincontaining protein 1 (Wwc1) (Basu-Roy et al. 2015), an upstream regulatory function of SOX2 in the Hippo cascade may also be assumed in the pituitary (stem cells), although this connection has still to be explored. 
Interestingly, elevated levels of $\mathrm{YAP} / \mathrm{TAZ}$ target genes (like Ctgf and Cyr61) were observed in the SC-SP stem cell compartment after pituitary injury (Willems et al. 2016). The Hippo pathway may thus be implicated in the regenerative response of the pituitary stem cells, in agreement with its involvement in (stem cell-driven) repair in other tissues like the intestine (Gregorieff et al. 2015) and heart (Heallen et al. 2013, Xin et al. 2013).

Taken together, very recent data suggest that the Hippo pathway is involved in pituitary embryogenesis, homeostasis and regeneration, likely through its action in the stem/progenitor cell compartment, but further experimental elaboration is needed.

\section{EGF/FGF: additional regulators of adult pituitary stem cell proliferation?}

Epidermal growth factor (EGF) and basic fibroblast growth factor (bFGF, also known as FGF2) are two commonly used mitogens to stimulate stem cell growth in sphere and adherent cell cultures (Chen et al. 2005, Lepore et al. 2007, Gleiberman et al. 2008, Yoshida et al. 2016a). With the exception of FGF signaling from the ventral diencephalon during embryogenesis, both growth factor systems are not highly documented in the pituitary.

EGF and bFGF have been shown to activate pituitary stem cell proliferation. Both factors increase the proportion of SP cells in mouse adult AP cell aggregate cultures through stimulation of the cells' proliferation (Chen et al. 2006). In addition, bFGF-treated mouse RP explants exhibit higher BrdU incorporation (Ericson et al. 1998), while bFGF-treated aggregates of adult rat AP cells show a higher proportion of nestin ${ }^{+}$ cells (Krylyshkina et al. 2005). bFGF may exert its proliferative effects through various mediators such as signal transducer and activator of transcription-3 (STAT3), ERK and AKT, as has been identified using a folliculostellate cell line, which may represent a certain pituitary stem cell subpopulation (Vlotides et al. 2009). Adult pituitary stem cells show prominent expression of the cognate receptors $E g f r$ and $F g f r 1 / 2$, which make them highly receptive to EGF and FGF signals (Chen et al. 2009) (Table 1). Moreover, these receptors are further upregulated in the pituitary stem cell compartment upon injury and during the neonatal growth phase (Gremeaux et al. 2012, Willems et al. 2016) (Table 1). Taken together, both growth factor pathways may provide additional cues for stem cell proliferation in the (activated) adult pituitary.

\section{Pituitary tumorigenesis: stem cell regulation going awry?}

Like in other tissues, deregulation of pituitary stem cells may be associated with or foreshadow the development of disorders like tumorigenesis. Pituitary adenomas represent the most common intracranial tumors. Although largely benign, significant morbidity is present mainly due to hormone hypersecretion and/or compression of neighboring tissue. Pituitary tumors are classified as hormone-producing adenomas (prolactinomas, somatotropinomas, corticotropinomas, thyrotropinomas and plurihormonal adenomas) and non-functional pituitary adenomas (NFPA), which do not measurably secrete hormones (Melmed 2011). In addition, craniopharyngiomas occur in the pituitary (sellar/ parasellar) region, representing rare epithelial tumors and categorized as adamantinomatous craniopharyngioma (ACP) and papillary craniopharyngioma (GastonMassuet et al. 2011, Garcia-Lavandeira et al. 2012). Whereas ACP represents the most common pediatric tumor of the pituitary, most probably originating from (ectopic) RP remnants, papillary craniopharyngiomas occur in adults (Esheba \& Hassan 2015).

In general, the molecular and cellular mechanisms underlying pituitary tumorigenesis are largely unknown, and only less than $5 \%$ have been assigned to genetic mutations (Melmed 2011). Treatment through transsphenoidal resection, irradiation and/or medicines is not highly satisfactory, also because of therapy resistance and recurrence in a substantial proportion of the patients.

Recently, 'cancer stem cells' (CSC) have been identified in various cancer types (Sergeant et al. 2009, Wouters et al. 2009, Clevers 2011). CSC are defined as the subpopulation of the tumor's cells that drives initial and recurrent growth, invasion, metastasis and/or therapy resistance. The origin of CSC is still much debated and may be diverse, ranging from mature tissue cells that become transformed and de-differentiated thereby resuming stemness properties, to stem cells of which the tight regulation goes awry resulting in aberrant (tumorigenic) growth.

Recently, candidate CSC populations have been identified in pituitary adenomas using different approaches. Of note, since pituitary tumors are predominantly benign, the cells are more correctly referred to as 'tumor stem cells' (TSC). Human pituitary adenoma cells were found to generate sphere-like structures in culture showing some, although limited, differentiation capacity (Xu et al. 2009b). Pituitary adenoma cells expressing the stemness marker CD133

Published by Bioscientifica Ltd. 
showed self-renewal and also limited differentiation capacity in another study (Würth et al. 2016). However, these cells were sensitive to the antiproliferative effect of drugs (in this case, dopamine/somatostatin chimeric agonists), which does not fit with the general concept of therapy resistance of TSC. In another recent study, CD15+ cells were identified in pituitary adenomas exhibiting higher sphere-forming capacity than the remaining cells, and upregulated expression of SOX2 (Manoranjan et al. 2016). The latter finding is in agreement with an earlier report that showed SOX2 expression in a candidate TSC population as identified by SP efflux capacity (Mertens et al. 2015). The pituitary tumor SP was found to have self-renewal competence and in vivo tumorigenic dominance (Mertens et al. 2015), as well as higher resistance to drugs (H Roose, F Mertens \& H Vankelecom, unpublished observations). Increased expression of SOX2 was also found in the mouse $\mathrm{Drd2} 2^{-/-}$pituitary tumor model (Mertens et al. 2015). Female Drd2-/ mice harboring a deletion of the dopamine receptor D2 (Drd2) gene eventually develop prolactinomas. $D r d 2^{-/-}$pituitaries were found to contain more SP and (proliferating) SOX2+ cells than control pituitaries (Mertens et al. 2015). Whether this finding means that the SOX2+ cells represent pituitary tumor-driving cells is not clear yet, although SOX2+ CSC have been reported in other tumor types (e.g. squamous cell carcinoma; Boumahdi et al. 2014). In a mouse model of ACP (see below), it was observed that the SOX2+ cells rather act as paracrine-regulatory cells of the developing tumors, promoting proliferation of the cells adjacent to the SOX2+ cells (Andoniadou et al. 2013). However, it should be noted that ACP is different from the typical AP (non-)endocrine tumors. Both in the tumor SP and in the ACP model, activation of stem cell regulatory networks (as discussed previously) has been observed suggesting that dysregulation of stem cells may be associated with pituitary tumorigenesis. Below, we summarize the current literature on these particular pathways in pituitary tumors, and where available (but still scarce), in the candidate TSC population.

\section{Dysregulation of NOTCH in pituitary tumorigenesis}

Because of its key role in (stem) cell maintenance, differentiation, proliferation and apoptosis, NOTCH dysregulation is logically also implicated in tumorigenesis as supported in a variety of cancers (e.g. colorectal, ovarian, breast; see Park et al. 2006, Yamaguchi et al. 2008, Serafin et al. 2011).
Expression of NOTCH pathway components has also been detected in pituitary adenomas and appears different in different tumor subtypes. In NFPA, NOTCH3 and $J A G 1$ expression was found significantly increased as compared to normal human pituitary tissue (Lu et al. 2013, Yavropoulou et al. 2015a,b). Activation of NOTCH signaling in NFPA is further supported by the decreased expression of DLK1, the inhibitor of canonical NOTCH signaling (Moreno et al. 2005). Strangely, the NOTCH target gene HES1 was found downregulated (Yavropoulou et al. $2015 b$ ). Plurihormonal pituitary adenomas also show downregulated expression of HES1 and HES5 suggesting diminished NOTCH activity although also expression of DLK1 was found repressed (Jiang et al. 2012). In prolactinomas, an increase in $\mathrm{NOTCH} 3$ and decrease in DLK1 has been described, suggestive of NOTCH pathway activation in these tumors (Evans et al. 2008). However, these results were not confirmed in a second study, while somatotropinomas show a significant reduction of NOTCH3 and JAG1 (Yavropoulou et al. 2015b). Together, the NOTCH pathway appears activated or repressed depending on the pituitary tumor subtype, although results so far are not consistent. Dysregulation may affect tumor initiation, growth, invasion and/or resistance as found in other cancers like colorectal, liver, ovarian and breast cancer (Park et al. 2006, Yamaguchi et al. 2008, Han et al. 2015, Zheng et al. 2015).

Regarding the proposed pituitary tumor TSC populations, knowledge on the NOTCH pathway is at present limited and only includes expression analysis. Upregulation of several different NOTCH pathway components has been reported. Pronounced expression of DLL1, JAG1, HES1, NOTCH1 and NOTCH2 was found in the pituitary tumor SP (Mertens et al. 2015) (Table 1) while other candidate TSC populations (i.e. tumorspheres and $\mathrm{CD} 133^{+}$cell populations) showed upregulation of DLL1, JAG2, NOTCH1 and NOTCH4 (Xu et al. 2009b, Würth et al. 2016), the latter NOTCH receptor subtype in general is more associated with endothelial cells.

\section{Dysregulation of WNT in pituitary tumorigenesis}

Involvement of the WNT pathway in tumorigenesis, through its effects on cell proliferation, fate, death, polarity and migration, has been described in multiple cancer types (e.g. hepatocellular carcinoma, pancreatic ductal adenocarcinoma, colon carcinoma; see Morin et al. 1997, Miyoshi et al. 1998, Zhang et al. 2013). Moreover, WNT-activated cells may represent CSC as has been

Published by Bioscientifica Ltd. 
reported for LGR5-expressing cells in intestinal adenomas and cancer (Schepers et al. 2012).

Increased expression of WNT4 has been observed in somatotropinomas, prolactinomas and thyrotropinomas when compared to normal pituitary tissue (Miyakoshi et al. 2008, Chambers et al. 2013). Since no change in subcellular $\beta$-catenin distribution was seen, it was proposed that the non-canonical WNT pathway is activated in these PIT1 lineage tumors, in agreement with WNT4 being a typical ligand in this pathway. However, other studies found nuclear accumulation of $\beta$-catenin, suggestive of a role of canonical WNT activity, in pituitary tumorigenesis (Nakashima et al. 2002, Hassanein et al. 2003, Campanini et al. 2010). The WNT target gene PITX2 was found to be overexpressed in NFPA (in comparison with normal pituitary) (Acunzo et al. 2011). Transduction of a dominant-negative PITX2 mutant in cultured human NFPA cells and in the mouse gonadotrope tumor cell line TT3-1 induced apoptosis, which may suggest an antiapoptotic role for the WNT target PITX2 during NFPA tumorigenesis (Acunzo et al. 2011, Rostad 2012).

At present, involvement of WNT activation in pituitary tumorigenesis is most clear for ACP. Mutations in the CTNNB1 gene-encoding $\beta$-catenin have been detected in a substantial number of ACP (Sekine et al. 2002, Hölsken et al. 2016). Several of these alterations render the $\beta$-catenin protein resistant to degradation, hence leading to its accumulation and WNT pathway activation. Microarray analysis of ACP showed increased expression of direct canonical WNT and TCF/LEF target genes (e.g. LEF1, AXIN2, PITX2) when compared to normal pituitary (Gaston-Massuet et al. 2011, Gump et al. 2015, Hölsken et al. 2016). In contrast, no upregulation of WNT pathway components was found in papillary craniopharyngioma (Garcia-Lavandeira et al. 2012, Esheba \& Hassan 2015, Hölsken et al. 2016, Goschzik et al. 2017), but interestingly, expression of the stemness markers SOX2, SOX9, OCT4 and KLF4 was observed (Garcia-Lavandeira et al. 2012). In a mouse model of ACP, activation of the WNT pathway by targeted expression of degradation-resistant $\beta$-catenin in $\mathrm{SOX}^{2}{ }^{+}$pituitary stem cells triggered a (transient) proliferation of the latter cell population (Gaston-Massuet et al. 2011, Andoniadou et al. 2013). However, the mutated SOX $2+$ cells did not directly give rise to the ACP tumor, but promoted the proliferation of the surrounding cells, probably through the secretion of SHH and WNT ligands (like Wnt5a, Wnt6, Wnt10a) in a forward signaling manner. Interestingly, tumorigenesis did not occur when expression of the degradation-resistant $\beta$-catenin was targeted to committed (PIT1 ${ }^{+}$) or mature $\left(\mathrm{GH}^{+}\right.$and $\left.\mathrm{PRL}^{+}\right)$pituitary cells, providing supportive evidence that WNT dysregulation (here, activation) in the pituitary stem cells is a key event in ACP tumor development. Upregulation of WNT pathway components was also observed in the candidate TSC SP of human pituitary adenomas (in comparison with the bulk non-SP of the tumor) (e.g. LEF1, LGR5, TCF7L1, WNT5A) (Mertens et al. 2015) (Table 1). Of note, nuclear accumulation of $\beta$-catenin may also be correlated with a loss of interaction with membranous E-cadherin, which is associated with tumorigenesis and invasion in various tissues (El-Bahrawy \& Pignatelli 1998) and which may represent a step in EMT.

\section{EMT in pituitary tumorigenesis}

EMT plays an important role in cancer pathogenesis, particularly in maintenance, resistance and progression toward locally invasive and/or metastatic conditions (Brabletz et al. 2005, Yang \& Weinberg 2008, De Craene \& Berx 2013). In addition, EMT appears implicated in senescence, which suppresses apoptosis and cell cycle progression and hence may (additionally) underlie therapy resistance (Browne et al. 2010). Interestingly, it has been shown that EMT promotes the generation and activity of CSC/TSC (Mani et al. 2008, Polyak \& Weinberg 2009, Scheel \& Weinberg 2012).

TGFB signaling is an important regulator of EMT (Fig. 1B), which is involved in its pro-oncogenic activity (Miyazono 2009). In apparent contrast, TGFB/SMAD signaling seems downregulated in human dopamineresistant prolactinomas (Li et al. 2015). However, TGFB has dual effects in the progression of cancer: it is not only pro-oncogenic (e.g. by stimulating proliferation) but can also act as tumor suppressor by inhibiting cell proliferation (Pardali \& Moustakas 2007, Santibãnza et al. 2011). EMT is inherently associated with downregulation of E-cadherin (Fig. 1B). In somatotropinomas, decreased expression of E-cadherin appears associated with increased tumor size and invasiveness and declined susceptibility to somatostatin analogs (Lekva et al. 2013). Gene expression profiling of human pituitary adenoma SP supports the occurrence of (partial) EMT in this candidate TSC population (Mertens et al. 2015) (Table 1). Epithelial markers (CDH1, CLDN1) were found downregulated (as compared to the bulk non-SP), whereas mesenchymal markers (FN1, VIM) and EMT mediators (SNAI1, SNAI2, $Z E B 1, Z E B 2)$ were upregulated. Also other regulators of http://joe.endocrinology-journals.org DOI: 10.1530/JOE-17-0083
๑) 2017 Society for Endocrinology Printed in Great Britain
Published by Bioscientifica Ltd 
EMT were found to be prominently expressed in the pituitary tumor SP (e.g. CXCR4, FOSL2, FOXC1, LEF1, MMP1). Furthermore, inhibition of CXCR4 signaling reduced in vitro EMT-associated cell motility as well in vivo xenograft tumor growth of the mouse corticotrope AtT20 tumor cell line (Mertens et al. 2015). Taken together, candidate TSC shows EMT-linked molecular characteristics but the (functional) significance in pituitary tumorigenesis needs further investigation.

\section{Dysregulation of SHH in pituitary tumorigenesis}

Aberration of SHH signaling has been linked with tumorigenesis in various tissues, as for instance found in pancreas (Kasai 2016), bladder (Syed et al. 2016) and prostate (Peng \& Joyner 2015). Similar to the NOTCH pathway, SHH activity appears to differ according to pituitary adenoma subtype. Although SHH pathway components are found downregulated in NFPA as compared to normal pituitary tissue, GLI1 is overexpressed in somatotropinomas (Yavropoulou et al. $2015 b$ ). No significant differences were observed between prolactinomas and normal pituitary tissue. Another study observed SHH production and GLI1 upregulation not only in somatotropinomas (and corticotropinomas), but also in prolactinomas (Pyczek et al. 2016). From the studies so far, it may appear that NOTCH and SHH signaling are regulated in opposite ways in the different tumor subtypes. It is not clear whether activation of the SHH pathway is associated with the tumorigenic process or rather reflects a compensatory (protective?) mechanism (Jiang et al. 2012, Yavropoulou et al. 2015a,b). Lower expression of SHH and GLI1 in a small cohort of the rare malignant pituitary carcinoma type in comparison with various kinds of benign pituitary adenomas may rather point to a protective role (Pyczek et al. 2016). SHH signaling may also be activated in ACP based on the observed increase in GLI1, GLI2, GLI3, PTCH1 and SHH expression (Gomes et al. 2015, Gump et al. 2015, Hölsken et al. 2016), but is not upregulated in papillary craniopharyngioma (Hölsken et al. 2016, Goschzik et al. 2017). As mentioned previously, transgenically induced ACP showed increased production of $\mathrm{SHH}$ by the $\beta$-catenin-activated $\mathrm{SOX} 2+$ cells, which then may contribute to ACP development and tumor cell proliferation (Andoniadou et al. 2012, 2013). Some SHH-associated genes were also found upregulated in the SP of human pituitary tumors when compared to the bulk non-SP (Mertens et al. 2015) (Table 1), and GLI1 expression seems to go together with SOX2 expression as analyzed in a cohort of pituitary adenomas (Lampichler et al. 2015).

\section{Dysregulation of Hippo in pituitary tumorigenesis?}

Deregulation of the Hippo pathway leading to elevated levels of YAP/TAZ has been found in several types of cancer (Harvey et al. 2013). Hippo signaling (i.e. repressing YAP/TAZ) may thus exert tumor-suppressive activity. The Hippo system may also interact with WNT signaling since Yap1 deletion blocked the development of adenomas in WNT-activated $A \mathrm{pc}^{-/-}$intestinal crypts (Gregorieff et al. 2015). Implication of Hippo in pituitary tumorigenesis is still uncharted although enrichment of various Hippo pathway components (e.g. LATS2, TEAD4, YAP1) and of the downstream targets CTGF and CYR61 has recently been reported in the SP of human pituitary adenomas when compared to the bulk non-SP of the tumor (Mertens et al. 2015) (Table 1).

\section{Dysregulation of EGF/FGF in pituitary tumorigenesis}

EGF and its receptor EGFR play an important role in different types of tumors (Yarden \& Pines 2012). Several studies have found the expression of EGF and/or EGFR in pituitary adenomas, sometimes associated with a more aggressive (invasive) phenotype (Lubke et al. 1995, LeRiche et al. 1996, Asa \& Ezzat 2002, Onguru et al. 2004, Cooper et al. 2011, Fukuoka et al. 2011, del Pliego et al. 2013). In ACP, EGF signaling has been reported to play a role in tumor cell migration (Hölsken et al. 2011). FGFs have been detected at elevated levels in pituitary adenomas when compared to normal pituitary (Asa \& Ezzat 2002). Increased expression of the growth factor receptors EGFR, FGFR1 and FGFR3 was detected in the candidate TSC SP population (Mertens et al. 2015), suggesting a role for the EGF/FGF pathway in their proliferation.

Taken together, knowledge on the involvement of NOTCH, WNT, EMT, SHH, Hippo and EGF/FGF signaling in pituitary tumorigenesis is still fragmentary and limited. Moreover, whether dysregulation of these pathways in the pituitary stem cells leads to generation of TSC, or whether TSC are simply regulated by these pathways, is at present also not clear. Unraveling the nature of these connections may reveal interesting and valuable therapeutic targets and lead to new approaches for treating pituitary tumors. For example, the SHH pathway may be inhibited by SMO antagonists, which has been shown as a promising perspective for treating ACP (Rimkus et al. 2016), and

Published by Bioscientifica Ltd 
blocking CXCR4 signaling may impede pituitary tumor growth (Barbieri et al. 2014, Mertens et al. 2015).

\section{Concluding remarks}

\section{Back to the future: regulatory pathways from pituitary embryogenesis reiterated in adult stem cells}

The field of pituitary stem cells has made a substantial leap forward over the past decade, especially with respect to their identification. Although more and more studies address the question of their involvement in postnatal pituitary processes, knowledge remains limited, not only regarding their function but also certainly regarding their regulation. The stem cells are highly quiescent in the stationary adult pituitary, but present as more active particularly during early-postnatal maturation, injurytriggered regeneration and tumorigenesis. Core stem cell regulatory pathways like NOTCH, WNT, EMT and SHH seem activated in the (tumor) stem cell compartment during these conditions. Since these pathways also play essential roles during pituitary embryogenesis, activation of the stem cells may picture a flashback toward the past embryogenic events. In addition to the 'old faithful' pathways classically involved in embryogenesis and stem cell regulation, Hippo may gather increasing importance and further complement these pathways to an assembly of 'the big five' that pull the regulatory strings. It is clear that deciphering the networks regulating the pituitary (tumor) stem cells will cross-fertilize the search for their function in the postnatal gland. To this end, conditional transgenic models activating or deleting core factors of the different regulatory pathways specifically in the pituitary and/or its stem cells are essential. A further challenge will be to identify the cells providing the secreted regulatory factors, being produced by the stem cells to act in an autoor juxtacrine manner, by the cells in the close vicinity, or more generally by the endocrine cells of the gland, potentially in a reciprocal interaction. This search will portray the composition of the stem cell niche(s) in the pituitary in further desired detail.

Last but not least, pituitary stem cells also gradually enter the new era of in vitro organ and disease modeling, for which knowledge on regulatory networks is of essential importance. Using patient-derived (pluripotent) stem cells, in vitro modeling may eventually lead to a better understanding of pituitary diseases and open perspectives on regenerative approaches in pituitary deficiencies.
Declaration of interest

The authors declare that there is no conflict of interest that could be perceived as prejudicing the impartiality of this review.

\section{Funding}

This work was supported by grants from the KU Leuven (Research Fund; GOA) and from the Fund for Scientific Research (FWO) - Flanders (Belgium). B C and A V are supported by a PhD Fellowship from the FWO, and H R from the IWT (Agency for Innovation by Science and Technology; Flanders, Belgium).

\section{Acknowledgements}

The authors thank the funding agencies as mentioned above for making their research possible.

\section{References}

Abrão MG, Leite MV, Carvalho LR, Billerbeck AEC, Nishi MY, Barbosa AS, Martin RM, Arnhold IJ \& Mendonca BB 2006 Combined pituitary hormone deficiency (CPHD) due to a complete PROP1 deletion. Clinical Endocrinology 65 294-300. (doi:10.1111/j.13652265.2006.02592.x)

Acunzo J, Roche C, Defilles C, Thirion S, Quentien MH, Figarella-Branger D, Graillon T, Dufour H, Brue T, Pellegrini I, et al. 2011 Inactivation of PITX2 transcription factor induced apoptosis of gonadotroph tumoral cells. Endocrinology 152 3884-3892. (doi:10.1210/en.2011-1216)

Alatzoglou KS, Andoniadou CL, Kelberman D, Buchanan CR, Crolla J, Arriazu MC, Roubicek M, Moncet D, Martinez-Barbera JP \& Dattani MT 2011 SOX2 haploinsufficiency is associated with slow progressing hypothalamo-pituitary tumours. Human Mutation 32 1376-1380. (doi:10.1002/humu.21606)

Allaerts W \& Vankelecom H 2005 History and perspectives of pituitary folliculo-stellate cell research. European Journal of Endocrinology $\mathbf{1 5 3}$ 1-12. (doi:10.1530/eje.1.01949)

Andersen B, Pearse RV, Jenne K, Sornson M, Lin SC, Bartke A \& Rosenfeld MG 1995 The Ames dwarf gene is required for Pit-1 gene activation. Developmental Biology 172 495-503. (doi:10.1006/dbio.1995.8040)

Andoniadou CL, Gaston-Massuet C, Reddy R, Schneider RP, Blasco MA, Le Tissier P, Jacques TS, Pevny LH, Dattani MT \& Martinez-Barbera JP 2012 Identification of novel pathways involved in the pathogenesis of human adamantinomatous craniopharyngioma. Acta Neuropathologica 124 259-271. (doi:10.1007/s00401-012-0957-9)

Andoniadou CL, Matsushima D, Mousavy Gharavy SN, Signore M, Mackintosh AI, Schaeffer M, Gaston-Massuet C, Mollard P, Jacques TS, Le Tissier P, et al. 2013 Sox2(+) stem/progenitor cells in the adult mouse pituitary support organ homeostasis and have tumor-inducing potential. Cell Stem Cell 13 433-445. (doi:10.1016/j.stem.2013.07.004)

Arnhold IJ, França MM, Carvalho LR, Mendonca BB \& Jorge AA 2015 Role of GLI2 in hypopituitarism phenotype. Journal of Molecular Endocrinology 54 141-150. (doi:10.1530/JME-15-0009)

Asa SL \& Ezzat S 2002 The pathogenesis of pituitary tumours. Nature Reviews Cancer 2 836-849. (doi:10.1038/nrc926)

Bae S, Bessho Y, Hojo M \& Kageyama R 2000 The bHLH gene Hes6, an inhibitor of Hes1, promotes neuronal differentiation. Development 127 2933-2943.

Baladrón V, Ruiz-Hidalgo MJ, Nueda ML, Díaz-Guerra MJM, García-Ramírez JJ, Bonvini E, Gubina E \& Laborda J 2005 Dlk acts as (c) 2017 Society for Endocrinology Printed in Great Britain 
a negative regulator of Notch1 activation through interactions with specific EGF-like repeats. Experimental Cell Research 303 343-359. (doi:10.1016/j.yexcr.2004.10.001)

Barbieri F, Thellung S, Würth R, Gatto F, Corsaro A, Villa V, Nizzari M, Albertelli M, Ferone D \& Florio T 2014 Emerging targets in pituitary adenomas: role of the CXCL12/CXCR4-R7 system. International Journal of Endocrinology 2014 753524. (doi:10.1155/2014/753524)

Barker N, van Es JH, Kuipers J, Kujala P, van den Born M, Cozijnsen M, Haegebarth A, Korving J, Begthel H, Peters PJ, et al. 2007 Identification of stem cells in small intestine and colon by marker gene Lgr5. Nature 449 1003-1007. (doi:10.1038/nature06196)

Barker N, Huch M, Kujala P, van de Wetering M, Snippert HJ, van Es JH, Sato T, Stange DE, Begthel H, van den Born M, et al. 2010 Lgr5(+ve) stem cells drive self-renewal in the stomach and build long-lived gastric units in vitro. Cell Stem Cell 6 25-36. (doi:10.1016/j. stem.2009.11.013)

Basu-Roy U, Bayin NS, Rattanakorn K, Han E, Placantonakis DG, Mansukhani A \& Basilico C 2015 Sox2 antagonizes the Hippo pathway to maintain stemness in cancer cells. Nature Communications 6 6411. (doi:10.1038/ncomms7411)

Batchuluun K, Azuma M, Yashiro T \& Kikuchi M 2017 Notch signalingmediated cell-to-cell interaction is dependent on E-cadherin adhesion in adult rat anterior pituitary. Cell and Tissue Research 368 125-133. (doi:10.1007/s00441-016-2540-5)

Batlle E, Henderson JT, Beghtel H, Van den Born MM, Sancho E, Huls G, Meeldijk J, Robertson J, Van de Wetering M, Pawson T, et al. $2002 \beta$-Catenin and TCF mediate cell positioning in the intestinal epithelium by controlling the expression of EphB/EphrinB. Cell 111 251-263. (doi:10.1016/S0092-8674(02)01015-2)

Bear KA, Solomon BD, Antonini S, Arnhold IJ, França MM, Gerkes EH, Grange DK, Hadley DW, Jääskeläinen J, Paulo SS, et al. 2014 Pathogenic mutations in GLI2 cause a specific phenotype that is distinct from holoprosencephaly. Journal of Medical Genetics $\mathbf{5 1}$ 413-418. (doi:10.1136/jmedgenet-2013-102249)

Bernardi H, Gay S, Fedon Y, Vernus B, Bonnieu A \& Bacou F 2011 Wnt4 activates the canonical-catenin pathway and regulates negatively myostatin: functional implication in myogenesis. American Journal of Physiology: Cell Physiology 300 1122-1138. (doi:10.1152/ ajpcell.00214.2010)

Bertran E, Caja L, Navarro E, Sancho P, Mainez J, Murillo MM, Vinyals A, Fabra À \& Fabregat I 2009 Role of CXCR4/SDF-1 $\alpha$ in the migratory phenotype of hepatoma cells that have undergone epithelial-mesenchymal transition in response to the transforming growth factor- $\beta$. Cellular Signalling 21 1595-1606. (doi:10.1016/j. cellsig.2009.06.006)

Boumahdi S, Driessens G, Lapouge G, Rorive S, Nassar D, Le Mercier M, Delatte B, Caauwe A, Lenglez S, Nkusi E, et al. 2014 SOX2 controls tumour initiation and cancer stem-cell functions in squamous-cell carcinoma. Nature 511 246-250 (doi:10.1038/nature13305)

Brabletz T, Jung A, Spaderna S, Hlubek F \& Kirchner T 2005 Opinion: migrating cancer stem cells - an integrated concept of malignant tumour progression. Nature Reviews Cancer 5 744-749. (doi:10.1038/ nrc1694)

Braune EB \& Lendahl U 2016 Notch - a goldilocks signaling pathway in disease and cancer therapy. Discovery Medicine 21 189-196.

Brinkmeier ML, Potok MA, Cha KB, Gridley T, Stifani S, Meeldijk J, Clevers H \& Camper SA 2003 TCF and Groucho-related genes influence pituitary growth and development. Molecular Endocrinology 17 2152-2161. (doi:10.1210/me.2003-0225)

Brinkmeier ML, Potok MA, Davis SW \& Camper SA 2007 TCF4 deficiency expands ventral diencephalon signaling and increases induction of pituitary progenitors. Developmental Biology 311 396-407. (doi:10.1016/j.ydbio.2007.08.046)

Browne G, Sayan AE \& Tulchinsky E 2010 ZEB proteins link cell motility with cell cycle control and cell survival in cancer. Cell Cycle $\mathbf{9}$ 886-891. (doi:10.4161/cc.9.5.10839)
Campanini ML, Colli LM, Paixao BMC, Cabral TPF, Amaral FC, Machado HR, Neder LS, Saggioro F, Moreira AC, Antonini SRR, et al. 2010 CTNNB1 gene mutations, pituitary transcription factors, and microRNA expression involvement in the pathogenesis of adamantinomatous craniopharyngiomas. Hormones and Cancer $\mathbf{1}$ 187-196. (doi:10.1007/s12672-010-0041-7)

Carbajo-Pérez E \& Watanabe YG 1990 Cellular proliferation in the anterior pituitary of the rat during the postnatal period. Cell and Tissue Research 261 333-338. (doi.org/10.1007/bf00318674)

Carvalho LR, Brinkmeier ML, Castinetti F, Ellsworth BS \& Camper SA 2010 Corepressors TLE1 and TLE3 interact with HESX1 and PROP1. Molecular Endocrinology 24 754-765. (doi:10.1210/me.2008-0359)

Cha KB, Douglas KR, Potok MA, Liang H, Jones SN \& Camper SA 2004 WNT5A signaling affects pituitary gland shape. Mechanisms of Development 121 183-194. (doi:10.1016/j.mod.2003.12.002)

Chambers TJ, Giles A, Brabant G \& Davis JR 2013 Wnt signalling in pituitary development and tumorigenesis. Endocrine-Related Cancer 20 101-111. (doi:10.1530/ERC-13-0005)

Chen J, Hersmus N, Van Duppen V, Caesens P, Denef C \& Vankelecom H 2005 The adult pituitary contains a cell population displaying stem/ progenitor cell and early embryonic characteristics. Endocrinology 146 3985-3998. (doi:10.1210/en.2005-0185)

Chen J, Crabbe A, Van Duppen V \& Vankelecom H 2006 The notch signaling system is present in the postnatal pituitary: marked expression and regulatory activity in the newly discovered side population. Molecular Endocrinology 20 3293-3307. (doi:10.1210/ me.2006-0293)

Chen J, Gremeaux L, Fu Q, Liekens D, Van Laere S \& Vankelecom H 2009 Pituitary progenitor cells tracked down by side population dissection. Stem Cells 27 1182-1195. (doi:10.1002/stem.51)

Chen M, Kato T, Higuchi M, Yoshida S, Yako H, Kanno N \& Kato Y 2013 Coxsackievirus and adenovirus receptor-positive cells compose the putative stem/progenitor cell niches in the marginal cell layer and parenchyma of the rat anterior pituitary. Cell and Tissue Research $\mathbf{3 5 4}$ 823-836. (doi:10.1007/s00441-013-1713-8)

Chen W, Yi JK, Shimane T, Mehrazarin S, Lin YL, Shin KH, Kim RH, Park NH \& Kang MK 2016 Grainyhead-like 2 regulates epithelial plasticity and stemness in oral cancer cells. Carcinogenesis 37 500-510. (doi:10.1093/carcin/bgw027)

Cheung LY, Rizzoti K, Lovell-Badge R \& Le Tissier PR 2013 Pituitary phenotypes of mice lacking the Notch signalling ligand Delta-Like 1 homologue. Journal of Neuroendocrinology 25 391-401. (doi:10.1111/ jne.12010)

Cheung LY, Davis SW, Brinkmeier ML, Camper SA \& Pérez-Millán MI 2017 Regulation of pituitary stem cells by epithelial to mesenchymal transition events and signaling pathways. Molecular and Cellular Endocrinology 445 14-26. (doi:10.1016/j.mce.2016.09.016)

Clevers H 2011 The cancer stem cell: premises, promises and challenges. Nature Medicine 17 313-319. (doi:10.1038/nm.2304)

Clevers H \& Nusse R 2012 Wnt/ß-catenin signaling and disease. Cell 149 1192-1205. (doi:10.1016/j.cell.2012.05.012)

Cohen MM 2010 Hedgehog signaling update. American Journal of Medical Genetics, Part A 152A 1875-1914. (doi:10.1002/ajmg.a.32909)

Cooper O, Vlotides G, Fukuoka H, Greene MI \& Melmed S 2011 Expression and function of ErbB receptors and ligands in the pituitary. Endocrine-Related Cancer 18 197-211. (doi:10.1530/ERC-110066)

Dasen JS, Martinez-Barbera JP, Herman TS, O'Connell S, Olson L, Ju B, Tollkuhn J, Baek SH, Rose DW \& Rosenfeld MG 2001 Temporal regulation of a paired-like homeodomain repressor/TLE corepressor complex and a related activator is required for pituitary organogenesis. Genes and Development 15 3193-3207. (doi:10.1101/ gad.932601)

De Craene B \& Berx G 2013 Regulatory networks defining EMT during cancer initiation and progression. Nature Reviews Cancer 13 97-110. (doi:10.1038/nrc3447) 
del Pliego MG, Aguirre-Benítez E, Paisano-Cerón K, Valdovinos-Ramírez I, Rangel-Morales C, Rodríguez-Mata V, Solano-Agama C, MartínTapia D, de la Vega MT, Saldoval-Balanzario M, et al. 2013 Expression of Eag1 K+ channel and ErbBs in human pituitary adenomas: cytoskeleton arrangement patterns in cultured cells. International Journal of Clinical and Experimental Pathology 6 458-468.

Dincer Z, Piao J, Niu L, Ganat Y, Kriks S, Zimmer B, Shi SH, Tabar V \& Studer L 2013 Specification of functional cranial placode derivatives from human pluripotent stem cells. Cell Reports 5 1387-1402. (doi:10.1016/j.celrep.2013.10.048)

Dong J, Feldmann G, Huang J, Wu S, Zhang N, Comerford SA, Gayyed MF, Anders RA, Maitra A \& Pan D 2007 Elucidation of a universal size-control mechanism in Drosophila and mammals. Cell 130 1120-1133. (doi:10.1016/j.cell.2007.07.019)

Douglas KR, Brinkmeier ML, Kennell JA, Eswara P, Harrison TA, Patrianakos AI, Sprecher BS, Potok MA, Lyons RH, MacDougald OA, et al. 2001 Identification of members of the Wnt signaling pathway in the embryonic pituitary gland. Mammalian Genome 12 843-851. (doi:10.1007/s00335-001-2076-0)

Edwards W, Nantie LB \& Raetzman LT 2016 Identification of a novel progenitor cell marker, Grainyhead-like 2 in the developing pituitary. Developmental Dynamics 245 1097-1106. (doi:10.1002/dvdy.24439)

El-Bahrawy MA \& Pignatelli M 1998 E-cadherin and catenins: molecules with versatile roles in normal and neoplastic epithelial cell biology. Microscopy Research and Technique 43 224-232. (doi:10.1002/ (SICI)1097-0029(19981101)43:3<224::AID-JEMT4>3.0.CO;2-Q)

Ericson J, Norlin S, Jessell TM \& Edlund T 1998 Integrated FGF and BMP signaling controls the progression of progenitor cell differentiation and the emergence of pattern in the embryonic anterior pituitary. Development 125 1005-1015.

Esheba GE \& Hassan AA 2015 Comparative immunohistochemical expression of $\beta$-catenin, EGFR, ErbB2, and p63 in adamantinomatous and papillary craniopharyngiomas. Journal of the Egyptian National Cancer Institute 27 139-145. (doi:10.1016/j.jnci.2015.06.003)

Evans CO, Moreno CS, Zhan X, McCabe MT, Vertino PM, Desiderio DM \& Oyesiku NM 2008 Molecular pathogenesis of human prolactinomas identified by gene expression profiling, RT-qPCR, and proteomic analyses. Pituitary 11 231-245. (doi:10.1007/s11102-007-0082-2)

Farin HF, Jordens I, Mosa MH, Basak O, Korving J, Tauriello DV, de Punder K, Angers S, Peters PJ, Maurice MM et al. 2016 Visualization of a short-range Wnt gradient in the intestinal stem-cell niche. Nature 530 340-343. (doi:10.1038/nature16937)

Fauquier T, Rizzoti K, Dattani M, Lovell-Badge R \& Robinson IC 2008 SOX2-expressing progenitor cells generate all of the major cell types in the adult mouse pituitary gland. PNAS 105 2907-2912. (doi:10.1073/pnas.0707886105)

Frías A, Lambies G, Viñas-Castells R, Martínez-Guillamon C, Dave N, García de Herreros A \& Díaz VM 2015 A switch in Akt isoforms is required for Notch-induced Snail1 expression and protection from cell death. Molecular and Cellular Biology 36 923-940. (doi:10.1128/ MCB.01074-15)

Fu Q \& Vankelecom H 2012 Regenerative capacity of the adult pituitary: multiple mechanisms of lactotrope restoration after transgenic ablation. Stem Cells and Development 21 3245-3257. (doi:10.1089/ scd.2012.0290)

Fu Q, Gremeaux L, Luque RM, Liekens D, Chen J, Buch T, Waisman A, Kineman R \& Vankelecom H 2012 The adult pituitary shows stem/ progenitor cell activation in response to injury and is capable of regeneration. Endocrinology 153 3224-3235. (doi:10.1210/en.20121152)

Fu HD, Wang BK, Wan ZQ, Lin H, Chang ML \& Han GL 2016 Wnt5a mediated canonical Wnt signaling pathway activation in orthodontic tooth movement: possible role in the tension force-induced bone formation. Journal of Molecular Histology 47 455-466. (doi:10.1007/ s10735-016-9687-y)
Fukuoka H, Cooper O, Ben-Shlomo A, Mamelak A, Ren SG, Bruyette D \& Melmed S 2011 EGFR as a therapeutic target for human, canine, and mouse ACTH-secreting pituitary adenomas. Journal of Clinical Investigation 121 4712-4721. (doi:10.1172/JCI60417)

Gage PJ, Suh H \& Camper SA 1999 The bicoid-related Pitx gene family in development. Mammalian Genome 10 197-200. (doi:10.1007/ s003359900970)

Garcia-Lavandeira M, Quereda V, Flores I, Saez C, Diaz-Rodriguez E, Japon MA, Ryan AK, Blasco MA, Dieguez C, Malumbres M, et al. 2009 A GRFa2/Prop1/Stem (GPS) cell niche in the pituitary. PLoS ONE 4 e4815. (doi:10.1371/journal.pone.0004815)

Garcia-Lavandeira M, Saez C, Diaz-Rodriguez E, Perez-Romero S, Senra A, Dieguez C, Japon MA \& Alvarez CV 2012 Craniopharyngiomas express embryonic stem cell markers (SOX2, OCT4, KLF4, and SOX9) as pituitary stem cells but do not coexpress RET/GFRA3 receptors. Journal of Clinical Endocrinology and Metabolism 97 E80-E87. (doi:10.1210/jc.2011-2187)

Gaston-Massuet C, Andoniadou CL, Signore M, Jayakody SA, Charolidi N, Kyeyune R, Vernay B, Jacques TS, Taketo MM, Le Tissier P, et al. 2011 Increased Wingless (Wnt) signaling in pituitary progenitor/stem cells gives rise to pituitary tumors in mice and humans. PNAS 108 11482-11487. (doi:10.1073/pnas.1101553108)

Gaston-Massuet C, McCabe MJ, Scagliotti V, Young RM, Carreno G, Gregory LC, Jayakody SA, Pozzi S, Gualtieri A, Basu B, et al. 2016 Transcription factor 7-like 1 is involved in hypothalamo-pituitary axis development in mice and humans. PNAS 113 548-557. (doi:10.1073/ pnas.1503346113)

Gleiberman AS, Michurina T, Encinas JM, Roig JL, Krasnov P, Balordi F, Fishell G, Rosenfeld MG \& Enikolopov G 2008 Genetic approaches identify adult pituitary stem cells. PNAS 105 6332-6337. (doi:10.1073/pnas.0801644105)

Glinka A, Dolde C, Kirsch N, Huang YL, Kazanskaya O, Ingelfinger D, Boutros M, Cruciat CM \& Niehrs C 2011 LGR4 and LGR5 are R-spondin receptors mediating Wnt/ $\beta$-catenin and Wnt/ PCP signalling. EMBO Reports 12 1055-1061. (doi:10.1038/ embor.2011.175)

Goldberg LB, Aujla PK \& Raetzman LT 2011 Persistent expression of activated Notch inhibits corticotrope and melanotrope differentiation and results in dysfunction of the HPA axis. Developmental Biology 358 23-32. (doi:10.1016/j.ydbio.2011.07.004)

Gomes DC, Jamra SA, Leal LF, Colli LM, Campanini ML, Oliveira RS, Martinelli CE, Moreira AC, Machado HR, Saggioro F, et al. 2015 Sonic Hedgehog pathway is upregulated in adamantinomatous craniopharyngiomas. European Journal of Endocrinology 172 603-608. (doi:10.1530/EJE-14-0934)

Goschzik T, Gessi M, Dreschmann V, Gebhardt U, Wang L, Yamaguchi S, Wheeler DA, Lauriola L, Lau CC, Müller HL, et al. 2017 Genomic alterations of adamantinomatous and papillary craniopharyngioma. Journal of Neuropathology and Experimental Neurology 76 126-134. (doi:10.1093/jnen/nlw116)

Gregorieff A, Liu Y, Inanlou MR, Khomchuk Y \& Wrana JL 2015 Yapdependent reprogramming of Lgr5+ stem cells drives intestinal regeneration and cancer. Nature 526 715-718. (doi:10.1038/ nature15382)

Gremeaux L, Fu Q, Chen J \& Vankelecom H 2012 Activated phenotype of the pituitary stem/progenitor cell compartment during the earlypostnatal maturation phase of the gland. Stem Cells and Development 21 801-813. (doi:10.1089/scd.2011.0496)

Gump JM, Donson AM, Birks DK, Amani VM, Rao KK, Griesinger AM, Kleinschmidt-DeMasters BK, Johnston JM, Anderson RCE, Rosenfeld A, et al. 2015 Identification of targets for rational pharmacological therapy in childhood craniopharyngioma. Acta Neuropathologica Communications 3 30. (doi:10.1186/s40478-015-0211-5)

Han B, Liu SH, Guo WD, Zhang B, Wang JP, Cao YK \& Liu J 2015 Notch1 downregulation combined with interleukin-24 inhibits invasion http://joe.endocrinology-journals.org

DOI: $10.1530 / \mathrm{JOE}-17-0083$
() 2017 Society for Endocrinology Printed in Great Britain
Published by Bioscientifica Ltd. 
and migration of hepatocellular carcinoma cells. World Journal of Gastroenterology 21 9727-9735. (doi:10.3748/wjg.v21.i33.9727)

Hao HX, Xie Y, Zhang Y, Charlat O, Oster E, Avello M, Lei H, Mickanin C, Liu D, Ruffner H, et al. 2012 ZNRF3 promotes Wnt receptor turnover in an R-spondin-sensitive manner. Nature 485 195-200. (doi:10.1038/ nature11019)

Hartwell KA, Muir B, Reinhardt F, Carpenter AE, Sgroi DC \& Weinberg RA 2006 The Spemann organizer gene, Goosecoid, promotes tumor metastasis. PNAS 103 18969-18974. (doi:10.1073/pnas.0608636103)

Harvey KF, Pfleger CM \& Hariharan IK 2003 The Drosophila Mst ortholog, hippo, restricts growth and cell proliferation and promotes apoptosis. Cell 114 457-467. (doi:10.1016/S0092-8674(03)00557-9)

Harvey KF, Zhang X \& Thomas DM 2013 The Hippo pathway and human cancer. Nature Reviews Cancer 13 246-257. (doi:10.1038/nrc3458)

Hassanein AM, Glanz SM, Kessler HP, Eskin TA \& Liu C 2003 -Catenin is expressed aberrantly in tumors expressing shadow cells: pilomatricoma, craniopharyngioma, and calcifying odontogenic cyst. American Journal of Clinical Pathology 120 732-736. (doi:10.1309/ EALE-G7LD-6W71-67PX)

Heallen T, Zhang M, Wang J, Bonilla-Claudio M, Klysik E, Johnson RL \& Martin JF 2011 Hippo pathway inhibits Wnt signaling to restrain cardiomyocyte proliferation and heart size. Science 332 458-461. (doi:10.1126/science.1199010)

Heallen T, Morikawa Y, Leach J, Tao G, Willerson JT, Johnson RL \& Martin JF 2013 Hippo signaling impedes adult heart regeneration. Development 140 4683-4690. (doi:10.1242/dev.102798)

Higuchi M, Yoshida S, Ueharu H, Chen M, Kato T \& Kato Y 2014 PRRX1 and PRRX2 distinctively participate in pituitary organogenesis and a cell-supply system. Cell and Tissue Research 357 323-335. (doi:10.1007/s00441-014-1861-5)

Himes AD \& Raetzman LT 2009 Premature differentiation and aberrant movement of pituitary cells lacking both Hes1 and Prop1. Developmental Biology 325 151-161. (doi:10.1016/j.ydbio.2008.10.010)

Hölsken A, Gebhardt M, Buchfelder M, Fahlbusch R, Blümcke I \& Buslei R 2011 EGFR signaling regulates tumor cell migration in craniopharyngiomas. Clinical Cancer Research 17 4367-4377. (doi:10.1158/1078-0432.CCR-10-2811)

Hölsken A, Sill M, Merkle J, Schweizer L, Buchfelder M, Flitsch J, Fahlbusch R, Metzler M, Kool M, Pfister SM, et al. 2016 Adamantinomatous and papillary craniopharyngiomas are characterized by distinct epigenomic as well as mutational and transcriptomic profiles. Acta Neuropathologica Communications 420. (doi:10.1186/s40478-016-0287-6)

Hrabě de Angelis M, Mclntyre J \& Gossler A 1997 Maintenance of somite borders in mice requires the Delta homologue Dll1. Nature 386 717-721. (doi:10.1038/386717a0)

Jiang Z, Gui S \& Zhang Y 2012 Analysis of differential gene expression in plurihormonal pituitary adenomas using bead-based fiber-optic arrays. Journal of Neuro-Oncology 108 341-348. (doi:10.1007/s11060011-0792-1)

Johnson R \& Halder G 2014 The two faces of Hippo: targeting the Hippo pathway for regenerative medicine and cancer treatment. Nature Reviews Drug Discovery 13 63-79. (doi:10.1038/nrd4161)

Kasai K 2016 GLI1, a master regulator of the hallmark of pancreatic cancer. Pathology International 66 653-660. (doi:10.1111/pin.12476)

Kelberman D, De Castro SC, Huang S, Crolla JA, Palmer R, Gregory JW, Taylor D, Cavallo L, Faienza MF, Fischetto R, et al. 2008 SOX2 plays a critical role in the pituitary, forebrain, and eye during human embryonic development. Journal of Clinical Endocrinology and Metabolism 93 1865-1873. (doi:10.1210/jc.2007-2337)

Kelberman D, Rizzoti K, Lovell-Badge R, Robinson IC \& Dattani MT 2009 Genetic regulation of pituitary gland development in human and mouse. Endocrine Reviews 30 790-829. (doi:10.1210/er.2009-0008)

Kioussi C, Briata P, Baek SH, Rose DW, Hamblet NS, Herman T, Ohgi KA, Lin C, Gleiberman A, Wang J, et al. 2002 Identification of a Wnt/Dvl/ $\beta$-catenin $\rightarrow$ Pitx 2 pathway mediating cell-type-specific

http://joe.endocrinology-journals.org

DOI: $10.1530 / J O E-17-0083$
() 2017 Society for Endocrinology Printed in Great Britain proliferation during development. Cell 111 673-685. (doi:10.1016/ S0092-8674(02)01084-X)

Krylyshkina O, Chen J, Mebis L, Denef C \& Vankelecom H 2005 Nestinimmunoreactive cells in rat pituitary are neither hormonal nor typical folliculo-stellate cells. Endocrinology 146 2376-2387. (doi:10.1210/ en.2004-1209)

Lamouille S, Xu J \& Derynck R 2014 Molecular mechanisms of epithelialmesenchymal transition. Nature Reviews Molecular Cell Biology 15 178-196. (doi:10.1038/nrm3758)

Lampichler K, Ferrer P, Vila G, Lutz MI, Wolf F, Knosp E, Wagner L, Luger A \& Baumgartner-Parzer S 2015 The role of proto-oncogene GLI1 in pituitary adenoma formation and cell survival regulation. EndocrineRelated Cancer 22 793-803. (doi:10.1530/ERC-15-0109)

Lekva T, Berg JP, Heck A, Lyngvi Fougner S, Olstad OK, Ringstad G, Bollerslev J \& Ueland T 2013 Attenuated RORC expression in the presence of EMT progression in somatotroph adenomas following treatment with somatostatin analogs is associated with poor clinical recovery. PLOS ONE 8 e66927. (doi:10.1371/journal.pone.0066927)

Lepore DA, Thomas GP, Knight KR, Hussey AJ, Callahan T, Wagner J, Morrison WA \& Thomas PQ 2007 Survival and differentiation of pituitary colony-forming cells in vivo. Stem Cells 25 1730-1736. (doi:10.1634/stemcells.2007-0012)

LeRiche V, Asa S \& Ezzat S 1996 Epidermal growth factor and its receptor (EGF-R) in human pituitary adenomas: EGF-R correlates with tumor aggressiveness. Clinical Endocrinology 81 656-662. (doi:10.1210/ jcem.81.2.8636285)

Leroy P \& Mostov KE 2007 Slug is required for cell survival during partial epithelial-mesenchymal transition of HGF-induced tubulogenesis. Molecular Biology of the Cell 18 1943-1952. (doi:10.1091/mbc.E06-09. 0823)

Li Y, Hibbs MA, Gard AL, Shylo NA \& Yun K 2012a Genome-wide analysis of N1ICD/RBPJ targets in vivo reveals direct transcriptional regulation of Wnt, SHH, and Hippo pathway effectors by Notch1. Stem Cells $\mathbf{3 0}$ 741-752. (doi:10.1002/stem.1030)

Li VS, Ng SS, Boersema PJ, Low TY, Karthaus WR, Gerlach JP, Mohammed S, Heck AJ, Maurice MM, Mahmoudi T, et al. 2012b Wnt signaling through inhibition of $\beta$-catenin degradation in an intact Axin1 complex. Cell 149 1245-1256. (doi:10.1016/j.cell.2012.05.002)

Li Z, Liu Q, Li C, Zong X, Bai J, Wu Y, Lan X, Yu G \& Zhang Y 2015 The role of TGF- $\beta /$ Smad signaling in dopamine agonist-resistant prolactinomas. Molecular and Cellular Endocrinology 402 64-71. (doi:10.1016/j.mce.2014.12.024)

Lodge EJ, Russell JP, Patist AL, Francis-West P \& Andoniadou CL 2016 Expression analysis of the Hippo cascade indicates a role in pituitary stem cell development. Frontiers in Physiology 7 1-11. (doi:10.3389/ fphys.2016.00114)

Lu L, Li Y, Kim SM, Bossuyt W, Liu P, Qiu Q, Wang Y, Halder G, Finegold MJ, Lee JS, et al. 2010 Hippo signaling is a potent in vivo growth and tumor suppressor pathway in the mammalian liver. PNAS 107 1437-1442. (doi:10.1073/pnas.0911427107)

Lu R, Gao H, Wang H, Cao L, Bai J \& Zhang Y 2013 Overexpression of the Notch3 receptor and its ligand Jagged1 in human clinically non-functioning pituitary adenomas. Oncology Letters 5 845-851. (doi:10.3892/ol.2013.1113)

Lubke D, Saeger W, Ludecke DK 1995 Proliferation markers and EGF in ACTH-secreting adenomas and carcinomas of the pituitary. Endocrine Pathology 6 45-55. (doi:10.1007/BF02914988)

Mani SA, Yang J, Brooks M, Schwaninger G, Zhou A, Miura N, Kutok JL, Hartwell K, Richardson AL \& Weinberg RA 2007 Mesenchyme Forkhead 1 (FOXC2) plays a key role in metastasis and is associated with aggressive basal-like breast cancers. PNAS 104 10069-10074. (doi:10.1073/pnas.0703900104)

Mani SA, Guo W, Liao MJ, Eaton EN, Ayyanan A, Zhou AY, Brooks M, Reinhard F, Zhang CC, Shipitsin M, et al. 2008 The epithelialmesenchymal transition generates cells with properties of stem cells. Cell 133 704-715. (doi:10.1016/j.cell.2008.03.027) 
Manoranjan B, Mahendram S, Almenawer SA, Venugopal C, McFarlane N, Hallett R, Vijayakumar T, Algird A, Murty NK, Sommer DD, et al. 2016 The identification of human pituitary adenoma-initiating cells. Acta Neuropathologica Communications 4 125. (doi:10.1186/s40478-0160394-4)

McNicol AM 1986 A study of intermediate lobe differentiation in the human pituitary gland. Journal of Pathology 150 169-173. (doi:10.1002/path.1711500304)

Melmed S 2003 Mechanisms for pituitary tumorigenesis : the plastic pituitary. Journal of Clinical Investigation 112 1603-1618. (doi:10.1172/ JCI200320401)

Melmed S 2011 Pathogenesis of pituitary tumors. Nature Reviews Endocrinology 7 257-266. (doi:10.1038/nrendo.2011.40)

Mertens F, Gremeaux L, Chen J, Fu Q, Willems C, Roose H, Govaere O, Roskams T, Cristina C, Becú-Villalobos D, et al. 2015 Pituitary tumors contain a side population with tumor stem cell-associated characteristics. Endocrine-Related Cancer 22 481-504. (doi:10.1530/ ERC-14-0546)

Miyakoshi T, Takei M, Kajiya H, Egashira N, Takekoshi S, Teramoto A \& Osamura RY 2008 Expression of Wnt4 in human pituitary adenomas regulates activation of the $\beta$-catenin-independent pathway. Endocrine Pathology 19 261-273. (doi:10.1007/s12022-008-9048-9)

Miyazono K 2009 Transforming growth factor-beta signaling in epithelialmesenchymal transition and progression of cancer. Proceedings of the Japan Academy: Series B, Physical and Biological Sciences 85 314-323. (doi:10.2183/pjab.85.314)

Miyoshi Y, Iwao K, Nagasawa Y, Aihara T, Sasaki Y, Imaoka S, Murata M, Shimano T \& Nakamura Y 1998 Activation of the $\beta$-catenin gene in primary hepatocellular carcinomas by somatic alterations involving exon 3. Cancer Research 58 2524-2527.

Mollard P, Hodson DJ, Lafont C, Rizzoti K \& Drouin J 2012 A tridimensional view of pituitary development and function. Trends in Endocrinology and Metabolism 23 261-269. (doi:10.1016/j. tem.2012.02.004)

Monahan P, Rybak S \& Raetzman LT 2009 The Notch target gene Hes1 regulates cell cycle inhibitor expression in the developing pituitary. Endocrinology 150 4386-4394. (doi:10.1210/en.2009-0206)

Moreno CS, Evans CO, Zhan X, Okor M, Desiderio DM \& Oyesiku NM 2005 Novel molecular signaling and classification of human clinically nonfunctional pituitary adenomas identified by gene expression profiling and proteomic analyses. Cancer Research 65 10214-10222. (doi:10.1158/0008-5472.CAN-05-0884)

Morin PJ, Sparks AB, Korinek V, Barker N, Clevers H, Vogelstein B \& Kinzler KW 1997 Activation of $\beta$-catenin-Tcf signaling in colon cancer by mutations in $\beta$-catenin or APC. Science 275 1787-1790. (doi:10.1126/science.275.5307.1787)

Mullor JL, Dahmane N, Sun T \& I Altaba AR 2001 Wnt signals are targets and mediators of Gli function. Current Biology 11 769-773. (doi:10.1016/S0960-9822(01)00229-9)

Nakashima M, Meirmanov S, Matsufuji R, Hayashida M, Fukuda E, Naito S, Matsuu M, Shichijo K, Kondo H, Ito M, et al. 2002 Altered expression of $\beta$-catenin during radiation-induced colonic carcinogenesis. Pathology: Research and Practice 198 717-724. (doi:10.1078/0344-0338-00326)

Nantie LB, Himes AD, Getz DR \& Raetzman LT 2014 Notch signaling in postnatal pituitary expansion: proliferation, progenitors, and cell specification. Molecular Endocrinology 28 731-744. (doi:10.1210/ me.2013-1425)

Niehrs C 2012 The complex world of WNT receptor signalling. Nature Reviews Molecular Cell Biology 13 767-779. (doi:10.1038/nrm3470)

Ocaña OH, Córcoles R, Fabra Á, Moreno-Bueno G, Acloque H, Vega S, Barrallo-Gimeno A, Cano A \& Nieto MA 2012 Metastatic colonization requires the repression of the epithelial-mesenchymal transition inducer Prrx1. Cancer Cell 22 709-724. (doi:10.1016/j. ccr.2012.10.012)
Olson LE, Tollkuhn J, Scafoglio C, Krones A, Zhang J, Ohgi KA, Wu W, Taketo MM, Kemler R, Grosschedl R, et al. 2006 Homeodomainmediated $\beta$-catenin-dependent switching events dictate cell-lineage determination. Cell 125 593-605. (doi:10.1016/j.cell.2006.02.046)

Onguru O, Scheithauer BW, Kovacs K, Vidal S, Jin L, Zhang S, Ruebel KH \& Lloyd RV 2004 Analysis of epidermal growth factor receptor and activated epidermal growth factor receptor expression in pituitary adenomas and carcinomas. Modern Pathology 17 772-780. (doi:10.1038/modpathol.3800118)

Ozone C, Suga H, Eiraku M, Kadoshima T, Yonemura S, Takata N, Oiso Y, Tsuji T \& Sasai Y 2016 Functional anterior pituitary generated in self-organizing culture of human embryonic stem cells. Nature Communications 7 10351. (doi:10.1038/ncomms10351)

Panciera T, Azzolin L, Fujimura A, Di Biagio D, Frasson C, Bresolin S, Soligo S, Basso G, Bicciato S, Rosato A, et al. 2016 Induction of expandable tissue-specific stem/progenitor cells through transient expression of YAP/TAZ. Cell Stem Cell 19 1-13. (doi:10.1016/j. stem.2016.08.009)

Pardali K \& Moustakas A 2007 Actions of TGF- $\beta$ as tumor suppressor and pro-metastatic factor in human cancer. Biochimica et Biophysica Acta (BBA): Reviews on Cancer 1775 21-62. (doi:10.1016/j. bbcan.2006.06.004)

Park JT, Li M, Nakayama K, Mao TL, Davidson B, Zhang Z, Kurman RJ, Eberhart CG, Shih IM \& Wang TL 2006 Notch3 gene amplification in ovarian cancer. Cancer Research 66 6312-6318. (doi:10.1158/00085472.CAN-05-3610)

Peng YC \& Joyner AL 2015 Hedgehog signaling in prostate epithelialmesenchymal growth regulation. Developmental Biology 400 94-104. (doi:10.1016/j.ydbio.2015.01.019)

Pérez Millán MI, Brinkmeier ML, Mortensen AH \& Camper SA 2016 PROP1 triggers epithelial-mesenchymal transition-like process in pituitary stem cells. eLife 5 e14470. (doi:10.7554/eLife.14470)

Polyak K \& Weinberg RA 2009 Transitions between epithelial and mesenchymal states: acquisition of malignant and stem cell traits. Nature Reviews Cancer 9 265-273. (doi:10.1038/nrc2620)

Potok MA, Cha KB, Hunt A, Brinkmeier ML, Leitges M, Kispert A \& Camper SA 2008 WNT signaling affects gene expression in the ventral diencephalon and pituitary gland growth. Developmental Dynamics 237 1006-1020. (doi:10.1002/dvdy.21511)

Pyczek J, Buslei R, Schult D, Hölsken A, Buchfelder M, Heß I, Hahn H \& Uhmann A 2016 Hedgehog signaling activation induces stem cell proliferation and hormone release in the adult pituitary gland. Scientific Reports 6 24928. (doi:10.1038/srep24928)

Raetzman LT, Ross SA, Cook S, Dunwoodie SL, Camper SA \& Thomas PQ 2004 Developmental regulation of Notch signaling genes in the embryonic pituitary: Prop1 deficiency affects Notch2 expression. Developmental Biology 265 329-340. (doi:10.1016/j. ydbio.2003.09.033)

Ren W, Lewandowski BC, Watson J, Aihara E, Iwatsuki K, Bachmanov AA, Margolskee RF \& Jiang P 2014 Single Lgr5- or Lgr6-expressing taste stem/progenitor cells generate taste bud cells ex vivo. PNAS 111 16401-16406. (doi:10.1073/pnas.1409064111)

Rimkus TK, Carpenter RL, Qasem S, Chan M \& Lo HW 2016 Targeting the sonic hedgehog signaling pathway: review of smoothened and GLI inhibitors. Cancers 8 1-23. (doi:10.3390/cancers8020022)

Rizzoti K \& Lovell-Badge R 2005 Early development of the pituitary gland: induction and shaping of Rathke's pouch. Reviews in Endocrine and Metabolic Disorders 6 161-172. (doi:10.1007/s11154-005-3047-7)

Rizzoti K, Akiyama H \& Lovell-Badge R 2013 Mobilized adult pituitary stem cells contribute to endocrine regeneration in response to physiological demand. Cell Stem Cell 13 419-432. (doi:10.1016/j. stem.2013.07.006)

Rostad S 2012 Pituitary adenoma pathogenesis: an update. Current Opinion in Endocrinology, Diabetes, and Obesity 19 322-327. (doi:10.1097/MED.0b013e328354b2e2) http://joe.endocrinology-journals.org

DOI: $10.1530 / \mathrm{JOE}-17-0083$
๑ 2017 Society for Endocrinology Printed in Great Britain
Published by Bioscientifica Ltd 
Santibãnza JF, Quintanilla M \& Bernabeu C 2011 TGF- $\beta$ /TGF- $\beta$ receptor system and its role in physiological and pathological conditions. Clinical Science 121 233-251. (doi:10.1042/CS20110340)

Sato T, Vries RG, Snippert HJ, van de Wetering M, Barker N, Stange DE, van Es JH, Abo A, Kujala P, Peters PJ, et al. 2009 Single Lgr5 stem cells build crypt - villus structures in vitro without a mesenchymal niche. Nature 459 262-265. (doi:10.1038/nature07935)

Savagner P 2010 The epithelial-mesenchymal transition (EMT) phenomenon. Annals of Oncology 21 89-92. (doi:10.1093/annonc/ mdq292)

Scheel C \& Weinberg RA 2012 Cancer stem cells and epithelialmesenchymal transition: concepts and molecular links. Seminars in Cancer Biology 22 396-403. (doi:10.1016/j.semcancer.2012.04.001)

Schepers AG, Snippert HJ, Stange DE, van den Born M, van Es JH, van de Wetering M \& Clevers H 2012 Lineage tracing reveals Lgr5+ stem cell activity in mouse intestinal adenomas. Science 337 730-735. (doi:10.1126/science.1224676)

Sekine S, Shibata T, Kokubu A, Morishita Y, Noguchi M, Nakanishi Y, Sakamoto M \& Hirohashi S 2002 Craniopharyngiomas of adamantinomatous type harbor $\beta$-catenin gene mutations. American Journal of Pathology 161 1997-2001. (doi:10.1016/S00029440(10)64477-X)

Seo E, Basu-Roy U, Gunaratne PH, Coarfa C, Lim DS, Basilico C \& Mansukhani A 2013 SOX2 regulates YAP1 to maintain stemness and determine cell fate in the osteo-adipo lineage. Cell Reports $\mathbf{3}$ 2075-2087. (doi:10.1016/j.celrep.2013.05.029)

Serafin V, Persano L, Moserle L, Esposito G, Ghisi M, Curtarello M, Bonanno L, Masiero M, Ribatti D, Stürzl M, et al. 2011 Notch3 signalling promotes tumour growth in colorectal cancer. Journal of Pathology 224 448-460. (doi:10.1002/path.2895)

Sergeant G, Vankelecom H, Gremeaux L \& Topal B 2009 Role of cancer stem cells in pancreatic ductal adenocarcinoma. Nature Reviews Clinical Oncology 6 580-586. (doi:10.1038/nrclinonc.2009.127)

Sobrado VR, Moreno-Bueno G, Cubillo E, Holt LJ, Nieto MA, Portillo F \& Cano A 2009 The class I bHLH factors E2-2A and E2-2B regulate EMT. Journal of Cell Science 122 1014-1024. (doi:10.1242/jcs.028241)

Sprinzak D, Lakhanpal A, LeBon L, Santat LA, Fontes ME, Anderson GA, Garcia-Ojalvo J \& Elowitz MB 2010 Cis-interactions between Notch and Delta generate mutually exclusive signalling states. Nature 465 86-90. (doi:10.1038/nature08959)

Suga H, Kadoshima T, Minaguchi M, Ohgushi M, Soen M, Nakano T, Takata N, Wataya T, Muguruma K, Miyoshi H, et al. 2011 Selfformation of functional adenohypophysis in three-dimensional culture. Nature 480 57-62. (doi:10.1038/nature10637)

Suh H, Gage PJ, Drouin J \& Camper SA 2002 Pitx2 is required at multiple stages of pituitary organogenesis: pituitary primordium formation and cell specification. Development 129 329-337. (doi:10.1016/08887543(90)90050-5)

Sun S \& Irvine KD 2016 Cellular organization and cytoskeletal regulation of the Hippo signaling network. Trends in Cell Biology 26 694-704. (doi:10.1016/j.tcb.2016.05.003)

Susa T, Kato T, Yoshida S, Yako H, Higuchi M \& Kato Y 2012 Pairedrelated homeodomain proteins Prx1 and Prx2 are expressed in embryonic pituitary stem/progenitor cells and may be involved in the early stage of pituitary differentiation. Journal of Neuroendocrinology $\mathbf{2 4}$ 1201-1212. (doi:10.1111/j.1365-2826.2012.02336.x)

Syed IS, Pedram A \& Farhat WA 2016 Role of Sonic Hedgehog (Shh) signaling in bladder cancer stemness and tumorigenesis. Current Urology Reports 17 11. (doi:10.1007/s11934-015-0568-9)

Tando Y, Fujiwara K, Yashiro T \& Kikuchi M 2013 Localization of Notch signaling molecules and their effect on cellular proliferation in adult rat pituitary. Cell and Tissue Research 351 511-519. (doi:10.1007/ s00441-012-1532-3)

Taniguchi Y, Yasutaka S, Kominami R \& Shinohara H 2002 Proliferation and differentiation of rat anterior pituitary cells. Anatomy and Embryology 206 1-11. (doi:10.1007/s00429-002-0271-8)
Tempé D, Casas M, Karaz S, Blanchet-Tournier MF \& Concordet JP 2006 Multisite protein kinase A and glycogen synthase kinase 3beta phosphorylation leads to Gli3 ubiquitination by SCFbetaTrCP. Molecular and Cellular Biology 26 4316-4326. (doi:10.1128/ MCB.02183-05)

Treier M, Gleiberman AS, O'Connell SM, Szeto DP, McMahon JA, McMahon AP \& Rosenfeld MG 1998 Multistep signaling requirements for pituitary organogenesis in vivo. Genes and Development 12 1691-1704. (doi:10.1101/gad.12.11.1691)

Treier M, O'Connell S, Gleiberman A, Price J, Szeto DP, Burgess R, Chuang PT, McMahon AP \& Rosenfeld MG 2001 Hedgehog signaling is required for pituitary gland development. Development 128 377-386.

Udan RS, Kango-Singh M, Nolo R, Tao C \& Halder G 2003 Hippo promotes proliferation arrest and apoptosis in the Salvador/Warts pathway. Nature Cell Biology 5 914-920. (doi:10.1038/ncb1050)

Vaca AM, Guido CB, del Valle Sosa L, Nicola JP, Mukdsi J, Petiti JP \& Torres AI 2016 The expansion of adult stem/progenitor cells and their marker expression fluctuations are linked with pituitary plastic adaptation during gestation and lactancy. American Journal of Physiology: Endocrinology and Metabolism 311 367-379. (doi:10.1152/ ajpendo.00077.2016)

Vankelecom H 2010 Pituitary stem/progenitor cells: embryonic players in the adult gland? European Journal of Neuroscience 32 2063-2081. (doi:10.1111/j.1460-9568.2010.07523.x)

Vankelecom H 2012 Pituitary stem cells drop their mask. Current Stem Cell Research and Therapy 7 36-71. (doi:10.2174/157488812798483467)

Vankelecom H 2016 Pituitary stem cells: quest for hidden functions. In Stem Cells in Neuroendocrinology, pp 81-101. Eds D Pfaff \& Y Christen. Berlin, Germany: Springer International Publishing, Cham. (doi:10.1007/978-3-319-41603-8_7)

Vankelecom H \& Chen J 2014 Pituitary stem cells: where do we stand? Molecular and Cellular Endocrinology 385 2-17. (doi:10.1016/j. mce.2013.08.018)

Vankelecom H \& Gremeaux L 2010 Stem cells in the pituitary gland: a burgeoning field. General and Comparative Endocrinology 166 478-488. (doi:10.1016/j.ygcen.2009.11.007)

Van Schoore G, Mendive F, Pochet R \& Vassart G 2005 Expression pattern of the orphan receptor LGR4/GPR48 gene in the mouse. Histochemistry and Cell Biology 124 35-50. (doi:10.1007/s00418-0050002-3)

Vlotides G, Chen YH, Eigler T, Ren SG \& Melmed S 2009 Fibroblast growth factor-2 autofeedback regulation in pituitary folliculostellate TtT/GF cells. Endocrinology 150 3252-3258. (doi:10.1210/en.20081625)

Wang Y, Martin JF \& Bai CB 2010 Direct and indirect requirements of Shh/Gli signaling in early pituitary development. Developmental Biology 348 199-209. (doi:10.1016/j.ydbio.2010.09.024)

Ward RD, Raetzman LT, Suh H, Stone BM, Nasonkin IO \& Camper SA 2005 Role of PROP1 in pituitary gland growth. Molecular Endocrinology 19 698-710. (doi:10.1210/me.2004-0341)

Werth M, Walentin K, Aue A, Schonheit J, Wuebken A, Pode-Shakked N, Vilianovitch L, Erdmann B, Dekel B, Bader M, et al. 2010 The transcription factor grainyhead-like 2 regulates the molecular composition of the epithelial apical junctional complex. Development 137 3835-3845. (doi:10.1242/dev.055483)

Willems C \& Vankelecom H 2014 Pituitary cell differentiation from stem cells and other cells: toward restorative therapy for hypopituitarism? Regenerative Medicine 9 513-534 (doi:10.2217/rme.14.19)

Willems C, Fu Q, Roose H, Mertens F, Cox B, Chen J \& Vankelecom H 2016 Regeneration in the pituitary after cell-ablation injury : timerelated aspects and molecular analysis. Endocrinology 157 705-721. (doi:10.1210/en.2015-1741)

Wouters J, Vankelecom H \& van den Oord J 2009 Cancer stem cells in cutaneous melanoma. Expert Review in Dermatology 4 225-235. (doi:10.1586/edm.09.17) 
Wu S, Huang J, Dong J \& Pan D 2003 Hippo encodes a Ste-20 family protein kinase that restricts cell proliferation and promotes apoptosis in conjunction with salvador and warts. Cell 114 445-456. (doi:10.1016/S0092-8674(03)00549-X)

Würth R, Barbieri F, Pattarozzi A, Gaudenzi G, Gatto F, Fiaschi P, Ravetti J-L, Zona G, Daga A, Persani L, et al. 2016 Phenotypical and pharmacological characterization of stem-like cells in human pituitary adenomas. Molecular Neurobiology [in press]. (doi:10.1007/ s12035-016-0025-x)

Xin M, Kim Y, Sutherland LB, Murakami M, Qi X, McAnally J, Porrello ER, Mahmoud AI, Tan W, Shelton JM, et al. 2013 Hippo pathway effector Yap promotes cardiac regeneration. PNAS 110 13839-13844. (doi:10.1073/pnas.1313192110)

Xu J, Lamouille S \& Derynck R 2009a TGF-beta-induced epithelial to mesenchymal transition. Cell Research 19 156-172. (doi:10.1038/ cr.2009.5)

Xu Q, Yuan X, Tunici P, Liu G, Fan X, Xu M, Hu J, Hwang JY, Farkas DL, Black KL, et al. $2009 b$ Isolation of tumour stem-like cells from benign tumours. British Journal of Cancer 101 303-311. (doi:10.1038/ sj.bjc.6605142)

Yamaguchi N, Oyama T, Ito E, Satoh H, Azuma S, Hayashi M, Shimizu K, Honma R, Yanagisawa Y, Nishikawa A, et al. 2008 NOTCH3 signaling pathway plays crucial roles in the proliferation of ErbB2negative human breast cancer cells. Cancer Research 68 1881-1888. (doi:10.1158/0008-5472.CAN-07-1597)

Yang J \& Weinberg RA 2008 Epithelial-mesenchymal transition: at the crossroads of development and tumor metastasis. Developmental Cell 14 818-829. (doi:10.1016/j.devcel.2008.05.009)

Yang J, Mani SA, Donaher JL, Ramaswamy S, Itzykson RA, Come C, Savagner P, Gitelman I, Richardson A \& Weinberg RA 2004 Twist, a master regulator of morphogenesis, plays an essential role in tumor metastasis. Cell 117 927-939. (doi:10.1016/j.cell.2004.06.006)

Yao C, Li P, Song H, Song F, Qu Y, Ma X, Shi R \& Wu J 2016 CXCL12/ CXCR4 axis upregulates Twist to induce EMT in human glioblastoma. Molecular Neurobiology 53 3948-3953. (doi:10.1007/s12035-0159340-x)

Yarden Y \& Pines G 2012 The ERBB network: at last, cancer therapy meets systems biology. Nature Reviews Cancer 12 553-563. (doi:10.1038/ nrc3309)

Yavropoulou MP, Maladaki A \& Yovos JG 2015a The role of Notch and Hedgehog signaling pathways in pituitary development and pathogenesis of pituitary adenomas. Hormones 14 5-18. (doi:10.14310/horm.2002.1570)

Yavropoulou MP, Maladaki A, Topouridou K, Kotoula V, Poulios C, Daskalaki E, Foroglou N, Karkavelas G \& Yovos JG 2015b Expression pattern of the Hedgehog signaling pathway in pituitary adenomas. Neuroscience Letters 611 94-100. (doi:10.1016/j.neulet.2015.10.076)
Yoshida S, Kato T, Yako H, Susa T, Cai LY, Osuna M, Inoue K \& Kato Y 2011 Significant quantitative and qualitative transition in pituitary stem/progenitor cells occurs during the postnatal development of the rat anterior pituitary. Journal of Neuroendocrinology 23 933-943. (doi:10.1111/j.1365-2826.2011.02198.x)

Yoshida S, Kato T, Higuchi M, Chen M, Ueharu H, Nishimura N \& Kato Y 2014 Localization of juxtacrine factor ephrin-B2 in pituitary stem/ progenitor cell niches throughout life. Cell and Tissue Research 359 755-766. (doi:10.1007/s00441-014-2054-y)

Yoshida S, Nishimura N, Ueharu H, Kanno N, Higuchi M, Horiguchi K, Kato T \& Kato Y $2016 a$ Isolation of adult pituitary stem/progenitor cell clusters located in the parenchyma of the rat anterior lobe. Stem Cell Research 17 318-329. (doi:10.1016/j.scr.2016.08.016)

Yoshida S, Kato T \& Kato Y $2016 b$ EMT involved in migration of stem/ progenitor cells for pituitary development and regeneration. Journal of Clinical Medicine 5 43. (doi:10.3390/jcm5040043)

Yoshimura F, Harumiya K, Ishikawa H \& Ohtsuka Y 1969 Differentiation of isolated chromophobes into acidophils or basophils when transplanted into the hypophysiotrophic area of hypothalamus. Endocrinologia Japonica 16 531-540. (doi:10.1507/endocrj1954.16.531)

Yu FX \& Guan KL 2013 The Hippo pathway: regulators and regulations. Genes and Development 27 355-371. (doi:10.1101/gad.210773.112)

Zhang Y, Morris JP, Yan W, Schofield HK, Gurney A, Simeone DM, Millar SE, Hoey T, Hebrok M \& di Magliano MP 2013 Canonical Wnt signaling is required for pancreatic carcinogenesis. Cancer Research $\mathbf{7 3}$ 4909-4922. (doi:10.1158/0008-5472.CAN-12-4384)

Zheng CG, Chen R, Xie JB, Liu CB, Jin Z \& Jin C 2015 Immunohistochemical expression of Notch1, Jagged1, NF-кB and MMP-9 in colorectal cancer patients and the relationship to clinicopathological parameters. Cancer Biomarkers 15 889-897. (doi:10.3233/CBM-150533)

Zhu X, Zhang J, Tollkuhn J, Ohsawa R, Bresnick EH, Guillemot F, Kageyama R \& Rosenfeld MG 2006 Sustained Notch signaling in progenitors is required for sequential emergence of distinct cell lineages during organogenesis. Genes and Development 20 2739-2753. (doi:10.1101/gad.1444706)

Zhu X, Gleiberman AS \& Rosenfeld MG 2007 Molecular physiology of pituitary development: signaling and transcriptional networks. Physiological Reviews 87 933-963. (doi:10.1152/physrev.00006.2006)

Zhu X, Tollkuhn J, Taylor H \& Rosenfeld MG 2015 Notch-dependent pituitary SOX2+ stem cells exhibit a timed functional extinction in regulation of the postnatal gland. Stem Cell Reports 5 1196-1209. (doi:10.1016/j.stemcr.2015.11.001)

Zimmer B, Piao J, Ramnarine K, Tomishima MJ, Tabar V \& Studer L 2016 Derivation of diverse hormone-releasing pituitary cells from human pluripotent stem cells. Stem Cell Reports 6 858-872. (doi:10.1016/j. stemcr.2016.05.005)

Received in final form 16 May 2017

Accepted 14 June 2017

Accepted Preprint published online 14 June 2017 http://joe.endocrinology-journals.org

DOI: $10.1530 / \mathrm{JOE}-17-0083$
() 2017 Society for Endocrinology Printed in Great Britain
Published by Bioscientifica Ltd. 